\title{
Marketing Shareholder Democracy in the Regions: Bell Telephone Securities, 1921-1935
}

\author{
DEIRDRE COLLIER \\ NANDINI CHANDAR \\ PAUL MIRANTI
}

This study widens the historical perspectives of how a firm coordinates its activities to simultaneously achieve financial and political ends while using regional efforts to enact a national strategy. It examines how AT\&T organized Bell Telephone Securities (BTS), a transitional subsidiary during the period 1921-1935, to broaden ownership of corporate shares and to develop political and cultural identities with Bell among small investors, particularly in the South and West. Equally significant was BTS's maintenance of liquidity of the Bell shares in the stock market, particularly in support of periodic rights offerings and debt conversions that were primary channels for increasing corporate equity. The subsidiary was eventually disbanded when its defining financial policies became unsustainable because of the radical socioeconomic and regulatory changes brought on by the Great Depression, but by this time many of its original objectives had been realized.

(C) The Author 2017. Published by Cambridge University Press on behalf of the Business History Conference.

doi:10.1017/eso.2016.62

Published online February 20, 2017

DeIRDRE COLlier is an associate professor of Accounting at Farleigh Dickinson University in Madison, NJ. E-mail: dcollier@fdu.edu

NANDini ChAndar is an associate professor of Accounting at Rider University, Lawrenceville, NJ. E-mail: nchandar@rider.edu

Paul Miranti is a professor of Accounting at Rutgers Business School-Newark and New Brunswick, NJ. He specializes in the history of accounting, finance, and quantitative business methods. E-mail: miranti@msn.com

The authors wish to acknowledge the support they received from William D. Caughlin, Sheldon Hochheiser, and George Kupczak at the AT\&T Archives; Tab Lewis at the National Archives; and Peter Asch, Janet Linde, and Steven Wheeler at the New York Stock Exchange Archives. They thank Lou Galambos and the members of the research seminar at the Johns Hopkins Institute of Applied Economics, Global Health and the Study of Business Enterprise for their many useful comments. They also benefitted from the excellent comments of two anonymous reviewers. 
This study widens the historical perspectives of how a firm coordinates its activities to simultaneously achieve financial and political ends while using regional efforts to enact a national strategy. We explore the use of marketing and public relations in the context of the shareholder democracy movement of the 1920s by investigating Bell Telephone Securities (BTS), a transitional subsidiary of American Telephone and Telegraph (AT\&T). ${ }^{1}$ We emphasize that corporate sponsorship was conditioned by the complementary objectives of exploiting economies from stock price support activities through strengthened financial market operating capabilities and the creation of a national political constituency. These objectives existed at the national level but needed to be realized regionally. As the largest publicly held corporation of its time, as well as the U.S. corporation with the broadest geographic spread, analysis of the activities of the Bell System gives insight into how U.S. corporations responded to the economic, political, and social challenges they faced. This has led, for example, to Roland Marchand's focus on AT\&T when discussing the changing role of advertising and public relations for firms in the early twentieth century, as well as its inclusion by Julia Ott in her broad survey of the shareholder democracy movement. ${ }^{2}$ Similarly, our work uses AT\&T as a model to explore the coordination of management's financing and political strategies in a national firm with largely regional operations.

Richard John's history of American telecommunications, while not expressly discussing investor democracy, does help to further understand the milieu surrounding BTS's emergence by examining the cultural and political environments in which the investor democracy movement flourished. ${ }^{3}$ Christopher Jones has noted that America's transformation from an organic to mineral energy regime was a selfreinforcing process, actively guided by corporate management, ${ }^{4}$ and echoes of this story can be detected in the growth of AT\&T. Like the change from reliance on wood to reliance on an electrical power grid, the dominance of the telephone as a communication device built on structures developed by earlier technologies, primarily the telegraph and postal services. Corporations promoted to the public the advantages

1. In this article, either AT\&T, the parent company of the Bell System Companies, or Bell System is used to refer to the combined companies of AT\&T, the regional operating companies, Bell Labs, Western Electric, Long Lines, and BTS. Although each company had its own leadership team, all were also under the leadership of AT\&T management, which coordinated activities of these firms and spoke as one voice for the entire Bell System.

2. Marchand, Corporate Soul, especially chapter 2; Ott, Wall Street Met Main Street, see especially chapter 7 for discussion of AT\&T.

3. John, Network Nation, chapter 8.

4. Jones, Routes of Power. 
of each new innovation. An innovation's technological advantages encouraged its adoption, which lowered its costs, leading to even wider usage. While beneficial to American society as a whole, the costs and benefits of the telephone, like the costs and benefits of the power generation, were unevenly distributed. In both cases, the main beneficiaries were urban centers and their suburban peripheries; rural areas benefitted far less. This pattern encouraged local opposition, which corporate interests needed to counter. By expanding corporate ownership to large numbers of average Americans, corporate interests sought to dampen or counter this local opposition.

As with other monopolistic enterprises in railroading and electrical power generation, the Bell System was deeply influenced by regional business dynamics. During its earliest years, the firm relied heavily on funds raised through locally franchised affiliates to finance the build-out of the network. Later, the parent company adopted a holding company structure that coordinated its activities, with the exception of long-distance services via more than a dozen of what would eventually be termed "regional Bell operating companies," or RBOCs in telephone-speak. Bell had extensive regional governmental exposure. It was in constant need of municipal construction variances, licenses, and rights of way. In addition, states were the sites of incorporation and shared oversight responsibility with two federal agencies: the Interstate Commerce Commission and, later, the Federal Communications Commission. Competition with the thousands of small independent telephone companies across all regions after the expiration of Alexander Graham Bell's patents in 1894-1895 led in 1913 to a broad agreement that compelled the company to curtail its horizontal expansion and open access to its long-distance grid to qualified local rivals. From a managerial perspective, there was also a push of national headquarters administrative practices into the regional units. A central statistical department, for example, served as a model for the subsequent formation of such capacities among the RBOCs. Most important, however, was how the new form of voice communication increased the efficiency of regional business by enhancing the ability to transfer ideas, coordinate action, and interact with a growing number of points of economic contact, all of which served Bell's fast-growing network. ${ }^{5}$ Indeed, the success of Bell's efforts to integrate regional operations within a national framework demonstrates the firm to be an exception to the contention that regional disparities within the United States led to business disorganization. ${ }^{6}$

5. Kenneth Lipartito addressed the history of large systems development and regional business for telephones in Bell System. John Larson addressed the history of the railroads in Bonds of Enterprise.

6. See, for example, Gordon, "Why No Corporatism in the United States?" 
Bell System historiography has generally taken one of two lines of research-the first relating to the firm's involvement in the political economy, ${ }^{7}$ and the second to its sociocultural initiatives. ${ }^{8}$ Integrating the study of investor democracy extends scholars' understanding by explaining how programs designed both to improve the image of the heavily regulated firm as a positive economic force and good corporate citizen and to broaden share ownership among small investors helped to defuse potential public opposition to its plans and policies. Bell, and other sponsors of broader public ownership, sought to surmount both a Progressive legacy of distrust that persisted in some circles about the economic and political power of giant business enterprise as well as the rejection of capitalism by more radical elements. By facilitating thrift and wealth-building through share purchases, the firm sought to extend the belief that such investment was an extension of traditional, republican American values. As recounted by Jonathan Levy, Americans' concepts of both security and democratic participation evolved in response to changes in American society over the nineteenth century. ${ }^{9}$ Reliance on a family farm for economic support faded as more people became wageworkers. At the same time, the idea of preparing for financial adversity-earlier feared through catastrophic weather events, then through loss of a job or a worker's ability to work-became envisioned as a responsibility that workers could meet through insurance, savings, and investing. It was at this juncture of changing notions about investing and democratic participation that Bell management sought to build a constituency of small shareholders, enacting a national strategy through local operations.

Adopting one of these two broad perspectives largely overlooks the strong penchant of Bell management to structure their commitments in ways that simultaneously achieved several complementary objectives. Although this type of operational multiplexing was deeply embedded in the Bell's organizational DNA, it is a pattern that remains largely unexplored in the large corpus of earlier studies dealing with firm management. ${ }^{10}$ The basic structure of Bell perforce

7. See Clarke, "Negotiating Between the Firm and the Consumer"; Green, Race on the Line; Lang, Phone of Our Own; Lipartito, "When Women Were Switches."

8. See Gabel and Weiman, "Historical Perspectives”; John, "Theodore Vail”; MacDougall, "Long Lines”; MacDougall, Peoples Telephone; Mueller, Universal Service.

9. Levy, Freaks of Fortune.

10. Adams and Butler, Manufacturing the Future; Galambos, "Theodore Vail”; Garnet, Telephone Enterprise; Lipartito, Bell System; Lipartito, "Rethinking the Invention Factory"; Reich, Making of American Industrial Research; Smith, Anatomy of a Business Strategy; Wasserman, From Invention to Innovation; Weiman, "Building 'Universal Service.", 
evinces its adherence to the notion of integrating complementary operations. The AT\&T holding company had grown strong through a structure that allowed the high-level coordination policies among its many regional operating subsidiaries-which allowed the firm to customize its services to local requirements-and Long Lines, its Western Electric manufacturing unit, and Bell Telephone Research Laboratories.

Importantly, by the 1920s, the identification and prioritization of challenges-as well as planned responses-for the Bell System as a whole came from the top. A degree of uniformity in prioritizing and then addressing problems enhanced the ability of management to plan and monitor operations. Such standardization was demonstrated in the firm's dissemination of mandatory procedures for plant maintenance, traffic management, inventory control, construction, and human resources. ${ }^{11}$ The difficult, and more complex, handling of rights offerings remained centralized, largely in the hands of New York corporate personnel. However, while AT\&T's management recognized challenges common to the entire system, it also saw that regional variations existed that would require differences in approach. Enlisting local Bell personnel in recruiting customer-shareholders allowed BTS to use the subsidiaries to target regional audiences for its financing efforts.

In the case of BTS, five interconnected objectives defined its operational scope. The first involved the build-up of political leverage by increasing the numbers of shareowners as a potential counter to the heavy firm regulation at all levels of government. The second concerned responsiveness to the social and cultural milieus by building, through advertising, education, and public relations, investor identification with the firm and its espousal of democratic and capitalistic values. The third related to the development of new capacities to attract equity funding capital from previously untapped sources to support the rapid growth of the firm during the 1920s. The fourth pertained to the establishment of new means for stabilizing prices and maintaining stock market liquidity of Bell shares, particularly in support of periodic rights offerings, and debt conversions that increased the number of shareholders and increased equity, the largest portion

11. This penchant for standardization even led to the distribution of booklets on guidelines for the organization of offices, down to the size and placement of desks. Annual conferences-whether for accounting, human resources, or plant operations-brought together regional and corporate management and served to define common Bell practices. Another area of standardization at Bell System at this time was the production of reports detailing operational and financial activities. In this effort, the firm mandated standard model graphs to be employed, which were developed by the firm's statistical department. For a discussion, see Chandar, Collier, and Miranti, "Graph Standardization." 
of Bell's long-term capitalization. ${ }^{12}$ Fifth, its sale of unexercised rights also helped to lower the overall cost of equity capital. These practices eventually ended with the disbanding of the subsidiary when its defining policies became unsustainable because of the radical socioeconomic and regulatory changes brought on by the Great Depression, but by this time many of its original objectives had been realized.

The Bell System leadership defined BTS's objectives in ways that sought to bolster the operational sustainability of the national telephone enterprise in the face of several challenges during a dynamic period in U.S. business history. The first was financial. AT\&T, the world's largest publicly held company, needed to attract sufficient funding to support the rapid expansion of its capital-intensive enterprise without incurring excessive levels of financial risk that might threaten the operation of its telephone network during periods of crises. The second related to the need to enhance managerial capacities for planning, coordinating, and controlling business activities of great scale, scope, and complexity. A third challenge involved responding to increasing regulatory oversight and political forces that constrained the power of the communications leviathan. Last, management endeavored to create a positive public image for the firm in an environment in which many concerns were voiced about the dangers of concentrated economic power to social equity and republican democracy. While these challenges did not originate in the 1920s, they gained sharp focus as the nation's attention turned homeward with the conclusion of World War I.

The Bell System's financial challenges were similar to those encountered by the monopolistic units that had come to dominate capitalintensive railroad, electrical utility, and communications industries early in the twentieth century. ${ }^{13}$ Unlike the manufacturing sector, in which giants like Standard Oil, DuPont, and General Electric had financed their respective growth largely from retained earnings, the utilities depended to a much greater extent on debt to build and maintain their extensive national or regional systems. Theoretically, these

12. Preemptive rights are the rights of existing shareholders to subscribe to new stock offering before the general public. In order to ward against dilution of existing shareholders' ownership percentages, firms issuing equity were required by law to first offer the shares to existing shareholders prior to soliciting new owners. AT\&T handled rights offerings by circulating letters to existing shareholders, alerting them to how many shares they were entitled to purchase per existing share held.

13. At the same time that the Bell System was using advertising and public relations to expand ownership, the electrical utility company Boston Edison was using marketing techniques to expand its customer base, as discussed by Sicilia, "Selling Power." Despite claims of business theorists that quasi-monopolies such as these would not need to aggressively advertise, the experience of both firms proved otherwise. 
companies should have been able to safely borrow more than manufacturers because of their strong market power; however, the risks of excessive leverage constrained their borrowing. To raise debt capital, they relied heavily on investment banking firms, such as the House of Morgan (in New York) or Kidder, Peabody (in Boston). ${ }^{14}$ Bankers placed most of these issues with insurance and trust companies or wealthy individuals in the United States and abroad. Despite market dominance, however, too much debt leverage could lead to financial disaster, as evinced by the extensive insolvencies among railroads during the financial crises of the 1870s and 1890s.

Raising equity capital also had its challenges. Investors had long considered equity investments to be speculative in part because of weaker property rights with respect to claims on income via dividends and on assets in the event of business dissolution. Moreover, unlike bond contracts, which provided precise information about returns, duration, and collateral useful in valuation, few companies provided the operational data that was necessary for projecting future profits and dividends.

The Bell System sought to diminish risk perceptions associated with the asymmetries that separated investors from their corporate agents by providing highly detailed annual reports. Additionally, in 1913, the firm began filing standardized financial statements with its national regulator, the Interstate Commerce Commission. Nevertheless, the firm operated in a context in which stock market investing was viewed by many as hazardous and akin to gambling. Speculation based on rumors and other unsubstantiated claims provided grist for marginal "bucket shops" that were essentially unregulated betting parlors. Security prices could be manipulated on exchanges through the concerted trading power of "pools" that overwhelmed transacting for particular shares. A significant incidence of fraud in securities dealing induced many states to promulgate "blue sky laws," which sought to ensure probity by registering brokers and controlling the flotation of new issues. ${ }^{15}$

Despite this history, in the early years of the twentieth century, equity markets began to strengthen and the number of investors expanded to meet the growing number of issuers. ${ }^{16}$ The success of the wartime Liberty and Victory Loan drives evinced the tremendous potential for raising capital from large populations of small investors. The Merrill

14. Carosso, Investment Banking in America; Carosso, Morgans; Carosso, Kidder, Peabody and Company Story.

15. Ott, Wall Street Met Main Street, 31-35; Carosso, Investment Banking in America, 156-164, 174-192.

16. For a discussion on the expansion of stock investing during the late nineteenth and early twentieth centuries, see Navin and Sears, "Rise of a Market." 
Lynch partnership, first formed in 1915, began building a pioneering national retail brokerage chain that, unlike the bucket shops, was differentiated by its professional advisory and planning services. Merrill Lynch recognized the middle class to be a huge, untapped capital market. ${ }^{17}$ Interest also grew in closed end mutual funds, which had existed in the United States since the 1890s. ${ }^{18}$ During the 1920s, firms such as Goldman Sachs and Lehman Brothers began to specialize in the floatation of equity issues. ${ }^{19}$ Capital-hungry utilities explored new modes of finance. As early as 1914, Pacific Gas and Electric sold shares directly to customers, partly as a means to counter the growth of a public ownership movement in its territory. Other utilities, including Public Service Corporation, the United Corporation, and Insull Utilities Investment Management, among others, pyramided investment through complex holding company arrangements to maximize opportunities for selling equity from component companies and to leverage earnings. ${ }^{20}$

The Bell System, however, was an outlier with respect to these general trends because of its relatively heavy reliance on equity over debt finance. From its founding in 1877, the firm had historically maintained low levels of debt leverage. The financial conservatism of the company's leadership doubtless also reflected sensitivity to the need to minimize all types of risk, both financial and operational, which could threaten the smooth functioning of their complex telecommunication system. The reliance of equity over debt to finance the firm's capital investments is show in figure 1. For example, in 1900, only 8 percent of the firm's $\$ 122$ million in assets was financed by long-term debt. ${ }^{21}$

The market operations of BTS and the employee stock purchase plan helped to enhance financial efficiency. They facilitated the growth of equity capital though preemptive rights offerings and through the conversion of debt to equity. Their market price support activities also contributed to the lowering of the 9 percent cost of equity capital based on the par value of its shares. This came about from the issuance of shares at steep premiums over par in the conversion of debt and in the sale by BTS of unexercised preemptive rights and of shares through installment financing. The effective rate of return fell in proportion to the increase over par in share issuances. Because of the extensive equity operations, the overall level of debt remained low. In 1916,

17. Perkins, Wall Street to Main Street.

18. The Massachusetts Investment Trust, the first opened end fund, began business in 1927.

19. Carosso, Investment Banking in America, 82-83.

20. Bonbright and Means, Holding Company, chapter 5; Carosso, Investment Banking, 295-299. For global evolution of public utility organization and finance, see Hausman, Hertner, and Wilkins, Global Electrification, chapter 4.

21. AT\&T, Annual Report of the Directors of the American Telephone and Telegraph Company (hereafter, Annual Report) 1900, calculated from data on 13. 


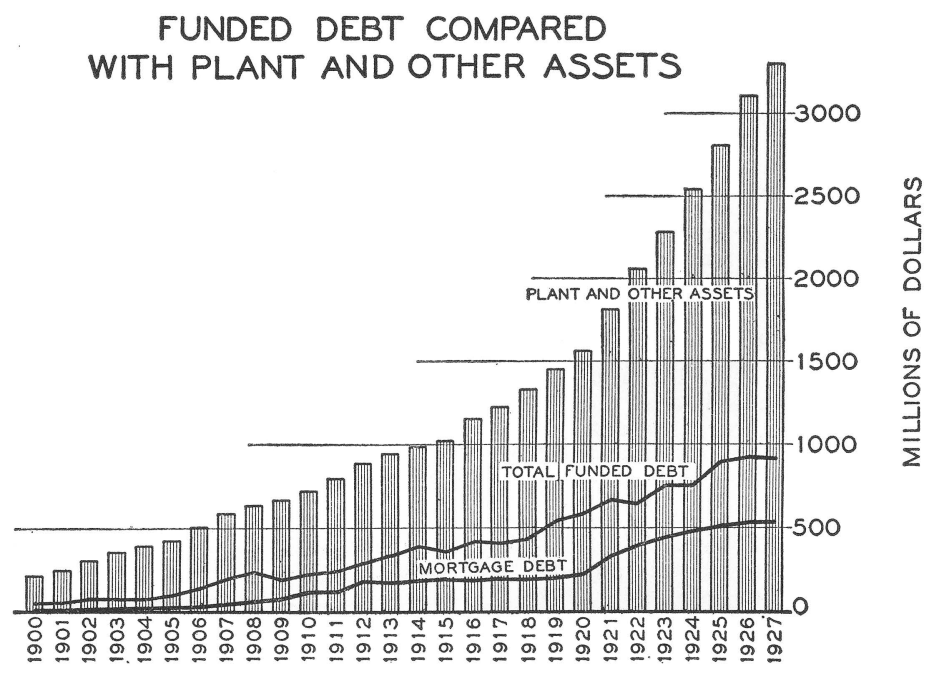

Figure 1 Bell System fixed assets and long-term debt, 1900-1927.

Source: AT\&T, Annual Report of the Directors of the American Telephone and Telegraph Company, 1927.

for example, long-debt funded only 28 percent of the $\$ 722$ million of assets, while capital stock and earned surplus accounted for 54 percent. $^{22}$ Reliance on equity as a capital source reinforced to management the importance of having stable stock prices, as the Bell treasury department's programs increased total shares outstanding from 569,000 in 1900 to 18.7 million in 1930.

Another challenge to organizational sustainability arose from the difficulty of managing a giant, geographically extensive enterprise. Beginning in the latter half of the nineteenth century, U.S. industry experienced major transformations as improvements in communications and transportation provided the basis for the emergence of an industrial-urban economy. Large companies, first in the railroads and then in manufacturing and public utilities, had to confront the problem of establishing managerial structures for planning, coordinating, and controlling business activities of great scale, scope, and complexity. ${ }^{23}$ The Pennsylvania Railroad successfully experimented with a structure involving a line-and-staff dichotomy to manage its horizontal integration. The line organization was responsible for daily operations of the system, while the central staff had responsibility for planning and oversight. More elaborate structures emerged in this sector as enterprises such as the refiner Standard Oil vertically integrated backward to acquire control of raw materials and forward

22. AT\&T, Annual Report 1916, calculated from data on 62 .

23. Galambos and Pratt, Rise of the Corporate Commonwealth, 5-16. 
to guarantee direct access to consumer markets. ${ }^{24}$ Explosives manufacturer DuPont diversified its product line to make use of underused resources, to reduce business risk, and to serve its new markets by establishing dedicated divisions or subsidiaries. ${ }^{25}$

Like many nascent utilities, the Bell System operated through a holding company structure with a parent corporate entity: in this case, AT\&T. This provided strategic and financial oversight to regional operating companies as well as direct customer service. The parent also controlled much of the system's equipment requirements through its Western Electric subsidiary. ${ }^{26}$ This structure initially operated very loosely, but central control through the parent increased greatly during the long presidency of Theodore N. Vail, starting in 1907. He introduced a "universal service" program that involved the standardization of technology and management practices. System monitoring and planning were strengthened through the proliferation of new sources of accounting, budgeting, and operating data. This enhanced the power of the center over the periphery and helped to ensure the same quality of service throughout the system. ${ }^{27}$ One culmination of this penchant for centralization was the organization in 1925 of the Bell Telephone Laboratories subsidiary as the exclusive center for the firm's research endeavors. ${ }^{28}$

The firm also had to respond to the mandates of an emerging regulatory regime, as demand for regulation rose with the evolution of huge corporations. Bigness in business was deemed to involve a potential trade-off of democratic values for material abundance. Although many Americans wanted the improvements in living standards from industrialization, they feared the market and political power of giant enterprises. ${ }^{29}$ As historians have noted, a major response to these developments in the United States was the establishment of new regulatory institutions and commissions that sought to control monopoly through administrative law. ${ }^{30}$ Regulation provided countervailing power against dominant companies, and it also mediated the allocation of the returns to the monopoly franchise among investors in the form of higher dividends and stock prices and the general public in the form of more efficient and economical service.

24. Chandler and Tedlow, Coming of Managerial Capitalism, 343-370.

25. Chandler and Salisbury, Pierre Du Pont.

26. Adams and Butler, Manufacturing the Future; Smith, Anatomy of a Business Strategy.

27. Garnet, Telephone Enterprise, chapter 9.

28. Gertner, Idea Factory; Lipartito, "Rethinking the Invention Factory"; Reich, Making of American Industrial Research.

29. Wiebe, Search for Order.

30. Schmoekel, "Liberty In or For the Market?”; Wagner, "Legal Perspectives." Additionally, see Skowronek, Building a New Administrative State, chapter 8. 
Railroads were the first to experience such regulation. Massachusetts led the way in 1869 by mandating the filing of financial statements to provide greater transparency for investors. ${ }^{31}$ In the following decade, because of the pressure of Grangers and other shipper groups, many states in the South and West sought to regulate the fairness of rates. ${ }^{32}$ In 1887 Congress established federal capabilities for advancing these policies through the formation of the Interstate Commerce Commission (ICC), which expanded its purview to the telephone industry in 1910 with the passage of the Mann-Elkins Act. ${ }^{33}$ Beginning in 1908, state commissions for regulating telephone service largely displaced earlier municipal oversight, with such boards increasing steadily to forty-five by $1915 .{ }^{34}$ The transfer of federal oversight authority from the ICC to the Federal Communications Commission (FCC) during the New Deal in 1934 greatly expanded the scope and power of federal oversight.

After the Bell System reincorporated in New York in 1900, partly to avoid restrictive features in Massachusetts' regulation, the firm successfully adjusted to the demands of both state and federal regulations through the Progressive era and the 1920s. The firm came to an agreement with the U.S. Justice Department in 1913 that enabled it to deflect anti-trust prosecution and to maintain its national system in return for an agreement to dissolve its controlling investment in Western Union Telegraph, to stop growing through acquisition of rival companies, and to provide independent telephone companies greater access to the Bell network. ${ }^{35}$ The ICC's monitoring was mild and accommodative, requiring, among other matters, that the firm develop and report using standardized financial statements and that it comply with the 1913 Valuation Act's requirements to provide estimates of both of the original and replacement costs of physical plants and facilities. During the regime of President Theodore Vail, the firm followed an explicit policy of cooperating with state and municipal boards as long as their policies were "fair and reasonable." 36 The importance of these governmental relationships was evinced by the formation in 1912 of a special bureau in the headquarter's statistical

31. McCraw, Prophets of Regulation, chapter 1.

32. Miller, Railroads and the Granger Laws.

33. This latter legislation differentiated the telephone industry from the electrical utilities, which were not subject to federal regulation until the passage of the Public Utility Holding Company Act in 1935.

34. Symkay, National Association of Railroad and Utility Commissioners, 22.

35. John, Network Nation, 359-363; Garnet, Telephone Enterprise 153-154, 158.

36. In AT\&T's 1913 Annual Report, Vail wrote: "Regulation by commissions of high standing composed of individuals of ability and integrity, and good impartial judgment, is the greatest protection to the public interests as against private exactions that ever was devised." AT\&T Annual Report 1913, 62. 
department, a bureau that exclusively prepared monthly reports on all regulatory decisions throughout the United States. ${ }^{37}$

New forces transforming the social landscape complicated the challenge of maintaining organizational sustainability. In the early twentieth century, America's populace rapidly changed as the country became increasingly urbanized and ethnically diverse. Among American elites, however, there was a worry that the social and political fluxes experienced by several European nations might erupt in the United States. ${ }^{38}$ This generation witnessed a successful Socialist revolution in Russia in 1917 and German upheaval in 1918-1919. The vying of Socialist, anarchist, and Labor candidates for elective office on the national as well as the state and local levels raised concerns about the preservation of property rights. In 1919 Bell's New England Telephone subsidiary experienced a disruptive strike of its telephone operators for better working conditions, pay, and the right to organize, which started in Boston, the original city for the Bell System's headquarters. This soon was followed by a disruptive Boston police strike, which induced Governor Calvin Coolidge to send in the National Guard to maintain public order. ${ }^{39}$ The "Red Scare" of 19191920, highlighted by a violent attack on the home of the U.S. attorney general and bombings on Wall Street, four blocks from AT\&T's New York headquarters, led to mass deportations of immigrants suspected of being active in radical political movements. ${ }^{40}$ Business and government leaders grappled with the appearance of homegrown Socialist movements, which sought to radicalize the working class. The concerns on the importation of radical beliefs that seemed contrary to traditional American values contributed to the imposition of a new immigration law that sharply curtailed the number of admissible immigrants from eastern and southern Europe.

It was in this context that the notion of investor, or industrial, democracy was born. ${ }^{41}$ Industrial democracy envisioned replacing the equation of proprietary democracy, in existence since Jeffersonian times, with a democracy evinced by those claiming an ownership stake in

37. S. L. Andrews, "Work of the Chief Statistician's Division with Special Reference to Certain Economic Studies Bearing Upon the Business Outlook,” File 185-03-01, General Accounting Conference, 1921, AT\&T Archives.

38. Murray, Red Scare; Hawley, Great War.

39. Russel, City in Terror.

40. Gage, Day Wall Street Exploded.

41. In this article, the terms "investor democracy," "shareholder democracy," and "industrial democracy" are used interchangeably. Industrial democracy is a term commonly used by writers of the early twentieth century (e.g., in the speeches of David Houston referenced throughout this article); investor democracy is the preferred term for current researchers, such as Julia Ott. See Ott, Wall Street Met Main Street. 
American capitalism. Stock ownership began to widen among a larger investor base, and financial markets and institutions that were once considered elitist evolved into foundations of American capitalism. Proponents of investor democracy endeavored to align the American public's social and economic interests with corporate enterprise by promoting broader public ownership of its investment securities. Widespread stock ownership would demonstrate broad public commitment to capitalistic institutions. Aligning corporate and public interests would also create an informal constituency that would be supportive of business-friendly legislation and policies. Investor democracy was expected to result in the formation of countervailing power by leading business enterprises against the new forces of government oversight and control. Recognizing that increased public ownership of corporations could answer several business needs, the business writer and equity promoter Edgar Smith noted that "the support of the public became increasingly of greater importance both financially and for protection against unwise legislation." 42

For individual investors, participation in financial markets also had become an element for individual financial security. With wages providing more than subsistence living, Americans had funds available to prudently put aside for a rainy day. The entry of the United States into World War I, and the government's decision to fund the war effort through issuing small denomination bonds, introduced many to their first experience of investing. Americans' positive experience with the Liberty Bond campaigns proved the viability of raising huge amounts of capital from the growing working and middle classes. The industrial democracy movement was the next step in this process; now, instead of lending their support to the government, the public would be asked to support and identify with American business.

Ownership of shares also created a psychic association with the firm's cultural image. By the 1920s, AT\&T had established a powerful image of technological and scientific leadership in the highgrowth field of telecommunications. Ownership of AT\&T shares allowed shareholders to become partners in the advancement of science for the greater good. Moreover, the characterization of shares as being appropriate for widows and orphans signaled how a wealthy and beneficent mother-“Ma Bell”-could be enlisted to protect society's most economically vulnerable. Cultivating such a public image helped counter the picture painted by Bell System critics who viewed the Bell Telephone System as grasping and dangerous to democracy. These perceptions were especially pernicious in rural areas in the

42. Smith, Common Stocks, 90. 
South and West, where the independent telephone companies had historically been strong. ${ }^{43}$

Although many corporations initiated stock ownership programs, it was especially important to AT\&T. Bell Telephone Systems was designed to facilitate the average American's purchase and holding of Bell System securities, especially in regions in which ownership of BTS shares was historically low. Using marketing and innovative sales plans, AT\&T created a national constituency of shareholders, becoming the most widely held public company in the world. Through BTS and its employee stock ownership plan, the firm succeeded in creating the largest class of stockholders in the nation, reaching a high of 650,000 in $1935 .{ }^{44}$

\section{Purpose and Vision}

The formation of BTS was planned in 1920, a year before its actual incorporation in Delaware in September 1921. President Harry B. Thayer (1919-1927) had a three-fold purpose in mind. Financially, AT\&T wanted to raise $\$ 100$ million in permanent capital to fund the Bell System's growth during the 1920s. Second, firm management perceived a need to fund expansion by attracting capital from new investors beyond the bounds of the predominant shareowner territory of the Northeast. As Thayer explained to Robert Winsor, managing partner of Kidder, Peabody:

We have become so large that we can no longer depend for our constituency on any one section of the country or on any one class of investors, but on the contrary, we must have as far as we can get it the understanding of and confidence of in our concern of the whole investing public. ${ }^{45}$

Concurrently, Thayer wanted to improve the image of the firm in the eyes of the public, especially prospective shareowners by offsetting

43. Paul Latzke's 1906 book, A Fight with an Octopus, portrayed the struggle between independents and the Bell System as one in which more than one honorable David battled an unscrupulous Goliath.

44. AT\&T, Annual Report 1935, 28.

45. Special Investigation Docket No. 1, "Letter from H. B. Thayer to Robert Winsor," May 20, 1920, Record Group 173, Entry 135, Box 25, Exhibit 252, FCC, National Archives. Box 25 contains information relating to the 1936 FCC investigation of the telephone industry. Included in this box is a summary of the information reviewed (Exhibit 250, "Report on Bell Telephone Securities") and an FCC discussion of whether to pursue legal action against AT\&T because of its financing activities (Exhibit 251). All other exhibit numbers relate to specific AT\&T documents examined by the FCC as part of its investigaton. 
"the misinformation which is and has been for some time in circulation regarding our affairs. Some of this is malicious but most of it is due to ignorance." 46

Although Bell might have relied on the agency of brokerage houses such as Kidder, Peabody, it elected for several reasons to rely instead on firm personnel to undertake this task. Thayer believed that the educational component of the stock plan-defining the mechanics of exercising rights-and the provision of information about the firm and its mission could be better controlled by Bell than by an outside party. Additionally, commission brokerage chains were just beginning to emerge during this period and did not have a national reach; Kidder, Peabody, for example, was largely limited to Massachusetts. There was also a fear of sullying the firm's image through misrepresentations made by unscrupulous brokers over whom Bell exercised little control. Furthermore, the rural clientele that the telephone giant desired to recruit often were situated in locales without access to brokerage services yet had local telephone company representatives. Finally, President Thayer anticipated an eventual need to sell preferred stocks in regional subsidiaries to local subscribers, which would be facilitated if Bell could make a market for these securities. ${ }^{47}$

The first step in the process of internalizing the new finance function was to determine the legality of Bell's involvement in a program for reacquiring and distributing its shares and the best organizational form to achieve this goal. In December 1920, after much internal discussion of this question, the firm's legal staff recommended that either a subsidiary through Western Electric be formed for this purpose or that AT\&T's articles of incorporation be modified to allow the formation of a finance subsidiary. ${ }^{48}$ The latter course of action was followed. ${ }^{49}$ However, some of the legal staff continued to worry that such a subsidiary might be challenged legally. They thought that the corporate veil might be pierced on the grounds that the wholly owned subsidiary had been formed to conduct transactions that the parent was prohibited from undertaking, such as taking dividends or exercising stock rights and voting shares. Second, there was concern about adverse public reaction to corporate activity, which would raise share prices from the firm's anticipated practice of open

46. Ibid.

47. Ibid.

48. Special Investigation Docket No. 1, "Memorandum on Certain Legal Aspects of the Creation and Control of Bell Telephone Securities," 1936, Record Group 173, Box 25, Exhibit 251, FCC, National Archives.

49. Special Invesitagation Docket No. 1, Edmund Hawley, "Memorandum for John H. Peck,” August 31, 1921, Box 25, Exhibit 266, FCC, National Archives. 
market purchases of its own shares. ${ }^{50}$ The advisability of organizing this subsidiary in the light of these uncertainties would eventually enter the public discourse after the dissolution of Bell Telephone Securities in 1935.

In making this choice, Bell differentiated its organizational structure for share distribution from the pattern followed by many contemporaneous electrical power companies. These latter enterprises operated through securities holding companies, which were not directly engaged in power transmission and thus not subject to state regulatory supervision. This option was irrelevant to Bell because it was subject to federal supervision through the ICC. This oversight was particularly problematic because of the possibility that the contemporaneous empowerment of the ICC to regulate railroad finance, under the Transportation Act of 1920, might be extended to the telephone industry. A wholly owned, non-operating subsidiary dedicated to securities trading and distribution doubtless seemed effective in confronting this eventuality.

Other reasons existed for operating through the new subsidiary Bell Telephone Securities, a name suggested by its future president, Walter S. Gifford. Although AT\&T, the parent company, could deal in Treasury shares, accounting for Treasury transactions resulted in direct adjustment of the firm's permanent capital rather than as profits because AT\&T was prohibited by corporate law from earning a profit in dealing in its own shares. However, the BTS subsidiary could record these transactions on its books as gains or losses, and thus qualify these items for inclusion in AT\&T's consolidated income statement. ${ }^{51}$

Equally important, but not explicitly acknowledged by Bell management, was the stock price stabilization effects that resulted from BTS's program, and the firm's public silence on this likely reflected management's concern about possible public criticism. The finance subsidiary fulfilled its subscriptions through the acquisition of AT\&T shares on the open market. Along with helping to provide liquidity for the parent's shares, management expected such support over time to maintain and then increase share value. A similar practice had been followed beginning in 1913 with the employee's retirement plan,

50. Special Investigation Docket No. 1, "Memorandum on Certain Legal Aspects of the Creation and Control of Bell Telephone Securities," Record Group 173, Box 25, Exhibit 251, FCC, National Archives; ibid., "Memorandum: Financing Program,” n.a., n.d., 4-5, Exhibit 287, FCC, National Archives.

51. Not includable in consolidated income would be gains or losses resulting from direct intercompany transactions between the parent and the subsidiary. Gains or losses resulting from dealing with independent third parties did qualify for consolidation. 
which was funded by AT\&T debentures. ${ }^{52}$ Along with Bell's employee stock purchase plan (formed in May 1921), which also served as its market agent, BTS controlled a share portfolio that had the ability to support prices at critical junctures, such as when new shares were distributed through rights offerings or bond conversions. ${ }^{53}$

A relatively unsuccessful rights offering completed in July 1921 was followed by the launch of BTS the following September. This occurred at the nadir of the 1920-1921 stock market decline that accompanied economic turmoil as the national economy rapidly shifted after World War I to a peacetime footing. About 7 percent of the rights went unexercised and the premium above par on average was less than $\$ 3$ per share for the 898,000 shares distributed..$^{54}$ Beyond market conditions, the poor showing was attributed to the fact that many shareholders were unfamiliar with the complexities of exercising their rights, while the traditional Eastern markets for Bell stock were surfeited.

BTS's launch also had a political dimension. The investment provided a link for developing support among the nation's middle class for the heavily regulated firm and its various agendas. Share ownership helped to create a common bond for making more concentric the sociopolitical outlooks of the company and the public. This perception was reflected in the instructions given to members of the commercial department of the Illinois Bell Telephone Company concerning their role in the "redistribution" of parent company shares. Both financial capital requirements and the coalescence of public support were given equal weight:

The first is that the public will, as a result, become more keenly interested in our problems and will come to understand them better, in other words, it is the best possible public relations' work. The second is that as our securities become more popular through a widespread distribution, the enormous amounts of capital required to develop the telephone business can be secured on a cheaper basis. ${ }^{55}$

The rationale for the closer linking of business and community was expressed through ideas first defined within the firm by Malcolm

52. Chandar and Miranti, "Development of Actuarial-Based Pension Accounting System."

53. For the date of initiation of the AT\&T plan and the number of employees it covered, see National Industrial Conference Board, Employee Stock Purchase Plans, 203.

54. Federal Communications Commission (FCC), Proposed Report, 514-516.

55. Special Investigation Docket No. 1, "Redistribution of American Telephone \& Telegraph Co. Stock through Sales,” 1936, Box 25 Exhibit 257, FCC, National Archives. 
Churchill Rorty, a vice president who had formed the Bell Systems statistical division under Vail and for a time was president of BTS. Rorty, an engineer, had a strong personal interest in economics and sociology. He was a founder of the National Bureau of Economic Research and a supporter of the work relating to business cycle analysis pursued by Professor Wesley C. Mitchell at Columbia University. His conservative perspective was reflected in his 1922 volume, Some Current Economic Problems, which considered how capitalism could effectively respond to Socialist criticisms about the equitable distribution of society's economic surplus. ${ }^{56}$

Rorty believed that it was important to promote "customer ownership" for natural monopolies, such as the fast-growing electrical utilities and electrical power companies, as a means to ensure "a natural and continuing relation of cooperation between the public and business." ${ }^{57} \mathrm{He}$ felt this could only emerge when ownership interests were broadly distributed and not concentrated in few hands. He envisioned a type of relationship that went beyond regulation. At its heart was the commitment of the enterprise to offer only the soundest securities to the public, commensurate with their level of investment knowledge. Novice investors would be encouraged to buy preferred shares, leaving common shares to the more experienced investors. Investment safety would be further ensured through the steady provision of reliable information about the firm and its prospects. ${ }^{58}$ The satisfaction of these requirements in Rorty's view had the potential:

[To create] an effective agency toward the development of habits of thrift; it offers sound investments at good rates of return to many who have lacked or been ignorant of such opportunities; it assists in the adequate development of utilities to meet community needs; and in the end it must conduce to the building up of relations of mutual confidence and helpfulness between the utilities and their customers. ${ }^{59}$

These purposes and visions would soon be implemented under the leadership of David F. Houston, BTS's president, who had played a leading role in helping the administration of U.S. President Woodrow Wilson to fund national defense efforts in World War I through the Liberty and Victory Loan programs. ${ }^{60}$ Houston served in the Wilson

56. Rorty, Some Problems in Current Economics.

57. Special Investigation Docket No. 1, Malcolm C. Rorty, "Notes on Customer Ownership," August 25, 1921, Box 25, Exhibit 258, FCC, National Archives.

58. Ibid.

59. Ibid.

60. Houston served as BTS president from 1921 to 1927. 
administration as both Secretary of Treasury and Secretary of Agriculture as well as as an ex officio member of the Federal Reserve Board. Importantly, he was on hand for the government's issue of four sets of Liberty Bonds in 1917 and 1918. Houston stated that the public's participation in funding World War I had revealed "the fact that there were vast numbers of small investors, who had savings and were willing to invest them." 61

\section{Sharpening the Vision}

Houston's management of the financing subsidiary sought to turn the large, dispersed American middle class into Bell investors, especially outside of the Northeast where the firm already had a strong investor base. Houston had excellent knowledge of conditions in the South and West. A native North Carolinian, he served as president of Agricultural and Mechanical College of Texas (19021905; now Texas A\&M), the University of Texas (1905-1908), and Washington University of St. Louis (1908-1913).

In addition to his considerable contribution to the financial management of the new subsidiary, Houston played a key role in refining and extending Rorty's earlier ideas about customer ownership into the more elaborate conceptual structure of the shareholder, or industrial democracy. Houston's beliefs on the benefits of industrial democracy stemmed in part from his perceptions about the changing nature and successful socialization of big business. ${ }^{62}$ From 1870 s to the 1890s, families or a small group of shareholders dominated the big businesses that emerged. Houston felt such big entities became unpopular because of the many mistakes and controversies associated with their growing power, which were eventually counterbalanced through the extension of laws and regulations.

Houston received support from academic allies in his efforts to develop public consciousness of the benefits of broader public share ownership. Significant in this regard was Harvard University Professor Thomas Nixon Carver, who had briefly served in the Department

61. Houston, “The Outlook,” 5, speech dated January 20, 1926, David Franklin Houston Papers, Houghton Library, Harvard University.

62. For an overview of Houston's views on democracy, see his article, “An Answer to Pessimists,” in Harper's Magazine, June 1924, 1-9. For his outline of the changing role of business and investors in America, see his address, "The Meaning and Strength of America," address to the Commercial Club of Chicago, January 13, 1927, David Franklin Houston Papers, Houghton Library, Harvard University. 
of Agriculture when Houston was the agency's secretary. ${ }^{63}$ Like Rorty, Carver eschewed political radicalism and argued strongly in his 1926 work, The Present Economic Revolution in the United States, for share-builder programs for employees and the general public to empower labor. ${ }^{64}$

The political economic scene began to stabilize after 1900 with the advance of Progressive reforms. This coincided with a discernible growth of public ownership of shares and life insurance policies that fostered strong financial linkages between small investors and the giant enterprises that were dominating the national economy. In his numerous speeches before business and finance groups, Houston pointed out that by 1925 small investors had accumulated sizeable amounts of common and preferred shares and life insurance through mutual insurance companies. In this way, he argued, labor and capital had created a new mutually beneficial relationship. In Houston's view, contemporaneous critics of capitalism were often "demagogues" who drew on outmoded beliefs about the nature of business, beliefs that were more appropriate for the 1870-1890 period. The critics failed to recognize the change in public attitudes and relationships with large businesses. Houston argued that the linking of labor and capital provided great assurance of the survival of capitalist institutions:

There is no assignable limit to the development of industrial democracy. The practice on the part of corporate businesses of inviting popular ownership is extending. Herein lies the solution of labor and capital. It is the real solution of the problem of partnership of labor and industry. And labor itself, as such, is embarking upon capitalistic enterprise. It recognizes that capital is the result of work and savings and that its destruction would cause a reversion to primitive practices. It will come more and more to perceive that the paramount need is to increase the world's output. To expand the amount that can be distributed, and to raise the standard of living of everybody. In such fashion are the foundations of American democracy being strengthened and through the process of evolution by which the workers are becoming capitalists, American democracy is being rendered impregnable. ${ }^{65}$

Houston ascribed American greatness to several factors, one of which was the freedom afforded the individual to experience personal

63. Carver, Recollections of an Unplanned Life, 175-176.

64. Carver, Present Economic Revolution, 100-104.

65. Houston, "Address Before the Twelfth Annual Convention of the Investment Bankers' Association,” 11-12, October 29, 1923, in Washington, DC, David Franklin Houston Papers, Houghton Library, Harvard University. 
growth and the opportunity to advance his or her material well-being. This potential was significantly extended by new linkages for translating the product of labor into the wealth-enhancing equity of public companies. The success of democracy also required the understanding of its unique definitions of the relationship between humankind and society, an understanding that was not automatic but had to be learned. Houston frequently illustrated this point through presentation of illiteracy statistics that purported to explain the failure of democracy in European countries during the 1920s. In America, however, educational levels were high, facilitating the understanding of the complex set of relationships that supported democracy. Knowledge and freedom combined to enable free men to pursue their self-interest. From the standpoint of material betterment, the freedom associated with democracy and the opportunity to participate through direct investment in the large businesses transforming the U.S. economy represented socioeconomic solutions to the Progressive's dilemma. Houston viewed the laws and regulations of the democratic polity as successfully constraining the abuses of power prevalent from the 1870 s to the 1890s, giving the average citizen the opportunity to benefit from industrial advancement through direct investment in the tamed lions of capitalistic endeavor.

The writings of both Rorty and Houston show Bell management contributed to an atmosphere where the ideals of democracy, capitalism, and freedom were intertwined. The firm sought to conflate the national telephone system-and AT\&T—with that of American democracy, as seen in the 1921 advertisement (figure 2) in which a diverse body of Americans-laborers and housewives, businessmen and maids-were seen as collectively supporting American industry (with the telephone prominently displayed). ${ }^{66}$

Management's vision of industrial democracy further benefited Bell System by facilitating the distribution of ownership in regions of the country that had shown little previous investor interest, particularly in the largely populist South and West. ${ }^{67}$ This meant relying on the insight and efforts of the local, regional Bell personnel. Quite possibly, management hoped that the spread of small-investor ownership in these regions would strengthen the firm's political position in the local rate regulation debates over how best to allocate the

66. New York Times, “23,480,000 Lines,” 27.

67. These regions were specifically mentioned as targets of BTS in speeches of its president, David Houston. See, for example, his speech presented to Bond Club of New York on October 22, 1925, 15; or his speech "The Telephone as a Factor in Modern Business," 12, presented to the Philadelphia Chamber of Commerce on January 14, 1926, David Franklin Houston Papers, Houghton Library, Harvard University. 


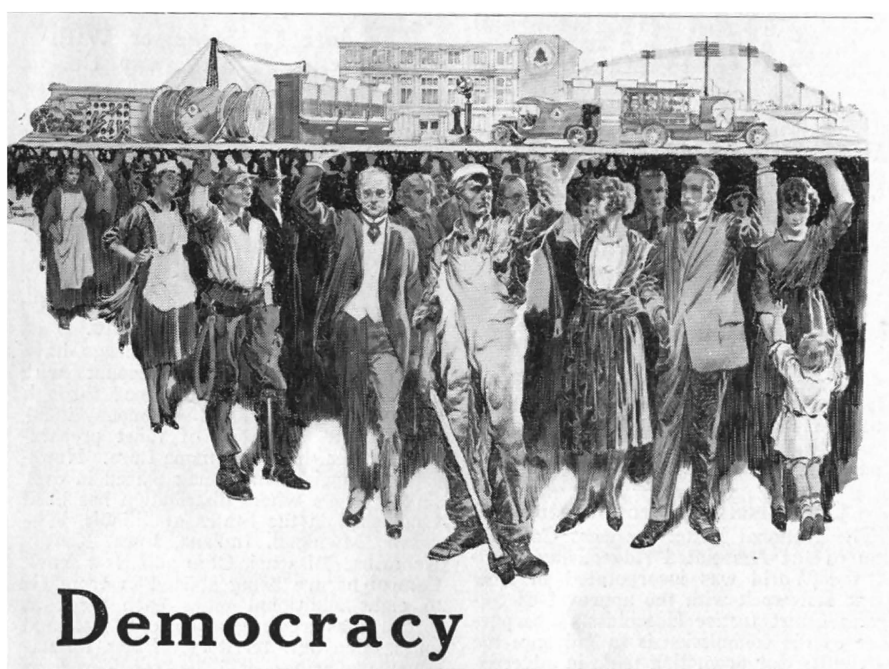

"- of the people, by the people, for the people"

People of every walk of life, in every state in the Union, are represented in the ownership of the Bell Telephone System. People from every class of telephone users, members of every trade, profession and business, as well as thousands of trust funds, are partners in this greatest investment democracy which is made up of the more than 175,000 stockholders of the American Telephone and Telegraph Company.

If this great body of people clasped hands they would form a line more than 150 miles long. Marching by your door, it would take more than 48 hours of ceaseless tramping for the line to pass.
This democracy of Bell telephone owners is greater in number than the entire population of one of our states; and more than half of its owners are women.

There is one Bell telephone shareholder for every 34 telephone subscribers. No other great industry has so democratic a distribution of its shares; no other industry is so completely owned by the people it serves. In the truest sense, the Bell System is an organization "of the people, by the people, for the people."

It is, therefore, not surprising that the Bell System gives the best and cheapest telephone service to be found anywhere in the world.

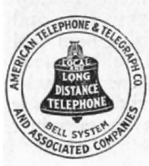

"Bell System"

AmERican TElephone and TElegraph Company AND Associated COMPANIES

One Policy, One System, Universal Service, and all directed toward Better Service

Figure $2 \mathrm{Ad}$ in the New York Times.

Source: Advertising and Selling, 1921.

costs of a vital public service. The creation of a national constituency, moreover, supported the firm's contention that it was involved in knitting together people spread across a continent, a contention most obviously demonstrated by the existence of the firm's long-distance 
operator-Long Lines ${ }^{68}$-but also actively expressed by the firm's marketing efforts. As claimed in one advertisement, the trunk lines of the Bell System were instrumental in "Uniting a Nation" by connecting "cities, towns, and rural communities."69

Changes in stock ownership were part of an overall changing picture of property ownership that reflected the evolution of the U.S. economy from rural to urban and from individual ownership of productive assets to corporate control. Bell management was not alone in seeing the ramifications of these changes. Adolf Berle and Gardiner Means, contemporaneous observers of the American corporate landscape, worried about potential problems that could arise from the separation of ownership and control of corporate assets. They observed that fundamental questions relating to ownership and management of property influenced "the political determination as to the kind of civilization the American state in its democratic processes has decided it wants." 70 The assets owned by the corporation were expected to benefit more than just the owners, and politics determined how much social cost should be borne by owners versus the public. Ensuring the existence of a shareholder group as a political constituency whose interests were aligned with those of the firm would be beneficial to any firm.

State-level entities exercised the most significant governmental power over the property rights of the telephone company. The broad purpose of state supervision was to protect the public interest by ensuring efficient and economical service. The economy standard pertained to reasonableness of cost, while efficiency related to the quality of transmission services. To achieve these goals, the regulatory bodies were endowed with broad authority to specify such matters as the costs recoverable through the rate base, the rules for financial accounting, the composition of corporate capital structure, and the types and level of employee compensation. ${ }^{71}$ The reality of operating under a multitude of state regulatory jurisdictions meant nearly continuous litigation over the firm's rates and rate structure. Building and maintaining a supportive national constituency could potentially minimize costly litigation. Public support, therefore, became an important sociopolitical issue to the firm.

68. For discussion on this business, see MacDougall, "Long Lines,” 297-327.

69. E. Katz Advertising Agency, "What Will 1921 Bring to Newspapers?" (advertisement), Advertising \& Selling Magazine 31 no. 8 (November 12, 1921): 27, Baker Old Class Collection, Baker Library, Harvard Business School, Cambridge, MA.

70. Berle and Means, Modern Corporation, xxiii.

71. In the United States, telephone rates were essentially calculated using a cost plus formula. Thus, defining operating costs, which were recoverable as separate from capital investments, was an important calculation in the eyes of regulators. 
Along with providing a source of necessary funds for capital expansion, creation of a public constituency for Bell could help to preserve the existing economic order if management was successful in aligning the interests of the firm with that of the broad shareholder-public constituency. With rising wages and the early retirement of Liberty Bonds used to finance American involvement in World War I, the timing of a program to increase corporate share ownership seemed propitious. Execution of this program, however, was problematic because the proper infrastructure did not exist to help turn savers into investors. BTS's operations met this need.

\section{Implementing the Vision}

In pursuing the vision of industrial democracy, BTS implemented four basic policies. First, it helped to stabilize the price of AT\&T stock through the steady purchase of shares as part of the effort to broaden ownership among both small investors and employees. Second, it enlisted employees, usually from its regional operating companies, to play an active role in the sale of securities. Third, it provided information to prospective investors about the firm's business and finances to induce purchases by reducing risk perceptions. Fourth, BTS explained the intricacies of exercising periodic preemptive stock rights, a major source of equity financing, to shareholders who lacked sufficient knowledge to take advantage of these offers.

BTS was not the first financing company created by the Bell System; prior to the formation of BTS, AT\&T had periodically incorporated subsidiary companies to assist in the sale of securities and in the acquisition of independent telephone companies. One such subsidiary, organized in 1906, was The Diamond State Co., which in 1909 acted as the agent of AT\&T in acquiring shares of Western Union Telegraph Company and in transactions involving several operating subsidiaries, including New York Telephone \& Telegraph Co. and Bell Telephone Co. of Buffalo. Another wholly owned finance subsidiary formed in 1903 was The Atlantic \& Pacific Telephone \& Telegraph Co. This company acted as the agent in acquiring minority shares held in associated companies and in acquiring independent companies and competitors. These initiatives were efforts on the part of Vail, as the new AT\&T president, in restructuring operating companies and territories. These short-term entities had important and specific regional targets. BTS, in contrast, was a Bell finance subsidiary that operated both regionally and nationally, and its operations were usually tailored to the specific requirements of the regions in which it operated. For example, the first campaign undertaken by BTS in 1921 was for Southwestern Bell, 
a widespread territory that required intensive organizing, beginning in several Texas cities before spreading to Kansas, Missouri, Arkansas, and Oklahoma. The campaign lasted three months and involved both Bell employees and local banks. In contrast, the second campaign, which was for Wisconsin Telephone, lasted only several weeks and relied primarily on sales by employee. ${ }^{72}$

As an extension and complement to its education program, BTS developed its "direct sales plans" with participating Bell operating subsidiaries by soliciting and processing share orders from small investors. The operating subsidiaries were the regional Bell companies, which provided local telephone services. Initially, the brokerage firm Kidder, Peabody had been selected to perform these functions because of its wholesale and retail capacities and its long professional association with the telephone enterprise. ${ }^{73}$ However, a major shortcoming of Kidder, Peabody was the fact that its retail business was largely centered in New England, where there was already a high concentration of Bell System owners. Unfortunately, there were no national commission houses at this time that could attract capital from all regions of the country. ${ }^{74}$ Nevertheless, the hope was that Kidder, Peabody would prove successful in increasing the volume of AT\&T share ownership among middle-class investors. However, Kidder, Peabody's charges for facilitating the national distribution of small share parcels proved unacceptably high. ${ }^{75}$ Moreover, regulatory barriers to expand the pool of owners also existed. New York State, where AT\&T was incorporated, required that new equity issues be offered to existing owners first, meaning that the only way new owners could usually acquire shares was on the open market. Open market transactions required the services of a brokerage firm; however, as noted by Houston, small investors did not have access to these services because "some of them liv[e] in communities which are further away from brokers than Cleveland is from New York."76

While the average small saver might not have been familiar with investment firms, they were familiar with the Bell System and its employees.

72. Houston, "Work of the Bell Telephone Securities Company," 15-19.

73. Carosso, Investment Banking in America.

74. Merrill Lynch, for example, which would eventually become a national institution, was only beginning its operations at this time. See Perkins, Wall Street to Main Street.

75. From June 2, 1920 through December 31, 1922, the brokerage firm received a 1 percent commission amounting to $\$ 2.1$ million and was reimbursed an additional \$1.5 million for promotional expenses. Kidder, Peabody \& Company, unsigned memo, "Costs Incurred in Respect to Publicity Campaign Conducted for AT\&T, to December 31, 1921," File 2180A, Loc. 540, Audio Room 04, AT\&T Archives.

76. Houston, "Talk at Bell Education Conference," 342, June 24, 1926, David Franklin Houston Papers, Houghton Library, Harvard University. 
According to Bell lore, customers began to ask if they could purchase shares directly from the phone company, initiating the direct sales experiment. ${ }^{77}$ When Bell employees made offerings of associated company preferred stock, their relative success as a sales and distribution force became apparent. As an example, the 1922 offering of almost 122,000 preferred shares of 7 percent Southwestern Bell was sold to 22,000 new subscribers-of which only 1,800 came through bank or brokerage channels. ${ }^{78}$ Emphasis was placed on employees as a sales force ${ }^{79}$; over the years, the differences in relative efforts were reflected by terming the sales campaigns as either light or intensive.

Under the BTS structure, AT\&T began consolidating customer orders collected at local telephone offices and placing these orders to acquire shares on the open market. Customer orders were for cash, either paid in full or in installments. By concentrating purchases in this way, BTS could reduce the basic sales fee to less than 25 cents per share. ${ }^{80}$ These charges were substantially lower than those that would have been incurred had small investors made odd-lot purchases through broker-dealers at the New York Stock Exchange. (Exchange investors had to pay an odd-lot dealer's charge of 50 cents per share as well as a broker's commission based on the value of the transaction.) Plan changes occurred periodically with an eye toward aiding the small investor: in 1931 the minimum monthly installment decreased to $\$ 10$ (from $\$ 20$ ); in 1932 the initial installment payment was decreased to $\$ 30$ (from $\$ 50$ ). ${ }^{81}$ For installment purchases, the parent company advanced funds to BTS to acquire and hold stock until the subscription was fully paid. BTS paid 6 percent interest on outstanding balances, ${ }^{82}$ a significant return on savings for the small investor. This also set the expectations for investors to receive a return of approximately 6 percent, a message communicated throughout the 1920s, during which time the firm often described its common stock in bond-like terms. AT\&T had long offered a 9 percent dividend on

77. Houston, "The Telephone as a Factor in Modern Business," 4.

78. Houston, "Some Aspects of the Telephone Business and Its Financing," 10, speech presented to the Massachusetts Bankers' Association in Boston, on January 7, 1925, David Franklin Houston Papers, Houghton Library, Harvard University.

79. The Bell System was unusual in its efforts to employ regular employees as part of a sales force for its securities, although this tactic was to some extent employed by utility companies. More common was the use of non-sales employees to sell products and services; for example, delivery boys were expected to sign up new customers during the Great Depression. See Postol, "Creating the American Newspaper Boy."

80. Houston, "Talk at Bell Education Conference," 342.

81. Changes noted in AT\&T Headquarters Bulletin, July 7, 1931, 2; and December 19, 1932, 6, respectively.

82. Blair-Smith, "1924 Stock Issue." 
$\$ 100$ par value stock. ${ }^{83}$ The cost of equity capital, however, was reduced if subsequent share issuances (deriving from rights offerings, debenture conversions, or installment sales) were made at high premiums over par. Thus, the average share market value of $\$ 136.9735$ for 1.5 million shares issued in the 1926 rights offering had an effective dividend rate of about 6.5 percent.

With a par value of $\$ 100$ and a higher market value, AT\&T shares were still expensive for the average American. The introduction of installment purchases allowed potential investors with limited capital to become AT\&T shareholders. ${ }^{84}$ BTS's establishment of a separate financing division was not unique. Installment sales were by now familiar to Americans; General Motors had formed General Motors Acceptance Corporation in the 1920s to promote selling automobiles on the installment plan, while less progressive Ford lost market share by offering consumers only a lay-away plan that required a contribution of $\$ 5$ per week until the car was completely paid for and before title transfer. ${ }^{85}$ AT\&T brought this installment model of consumerism into its strategy of share sales to widen its shareholder base. Although other utility firms sometimes allowed customers to purchase shares when paying their bills, AT\&T had a more aggressive use of installment stock purchases. ${ }^{86}$

Another function of BTS was to help stabilize AT\&T share prices by acquiring large blocks of parent company shares on the open market in anticipation of subscription fulfillment. The price support efforts were generally successful until the shock of the great crash of 1929. From 1923 to 1926, for example, BTS's purchases on behalf of small investors and employees represented between 21 percent and 38 percent of the average daily AT\&T share volume (which numbered in the several thousands) on the New York Stock Exchange and Boston Stock Exchange. ${ }^{87}$ Another index of market influence was that BTS was "ranked from sixth to second in number of shares voted by single stockholders between 1926 and 1932." $" 88$

83. For a summary of all preferred and common dividend payments by AT\&T and its major subsidiaries from 1901 to 1923, see Stehman, Financial History, Appendix VII, 327.

84. Installment sales allowed small investors to purchase AT\&T stock while the firm maintained its $\$ 100$ par value, in contrast to the approach pursued by the Standard Oil Company.

85. Hyman Debtor Nation, chapter 2.

86. Markham, Financial History of the United States, 123.

87. FCC, Investigation of the Telephone Industry, 14.

88. Special Investigation Docket No. 1, "Memorandum on Certain Legal Aspects of the Creation and Control of Bell Telephone Securities," 1936, Record Group 173, Box 25, Exhibit 251, 21n59, FCC, National Archives. 
Market price support operations also facilitated the rights offerings that enabled existing shareholders to maintain their proportional interest in the firm's equity. From 1921 to 1930, through six such offerings, shareholders could subscribe for a new share at par value of $\$ 100$, irrespective of market prices, for each five or six shares already owned. ${ }^{89}$ Shareholders benefited from the ability to acquire additional equity at a discount if the market price stayed above par. Approximately 35 percent to 40 percent of the shareowners during this era, on average, held only three shares, resulting in fractional ownership of rights. Because of this, about a half of the total rights granted during this period were sold into the market to other investors. ${ }^{90}$ In this case, the proceeds from the rights sale functioned in effect as a dividend to the seller. The higher the market price, the more attractive was this form of financing. Between 1921 and 1935, AT\&T shares varied in price, from a low of $\$ 70.23$ (1933) to a high of $\$ 310.25$ (1929). ${ }^{91}$ During that same period, Bell issued 8.5 million new shares, which represented about 47 percent of the 18.6 million outstanding in $1935 .{ }^{92}$

Market support activities of BTS and the employee stock purchase program helped to lower the firm's cost of capital and increased total shares outstanding through debt conversions to equity, through the sale of unsubscribed rights, and through installment sales of shares to employees. From 1923 through 1931, Bell issued more than four million shares for these purposes, at a premium over par, aggregating $\$ 217$ million. The premium reduced the effective dividend rate from 9 percent based on the par value to about 5.8 percent. ${ }^{93}$ Overall, this resulted in a lower cost of equity capital; in 1935, for example, the cost of equity capital stock amounted to 7.87 percent as compared to the 9 percent dividend rate. ${ }^{94}$

As part of its efforts to eliminate informational asymmetries that would deter middle-class investors, BTS lowered information costs among AT\&T shareowners who had a poor understanding of the firm's periodic rights offerings. By exercising rights, existing stockholders could ensure that the upcoming stock offering did not dilute their ownership. Many small investors, however, were confused by the idea of stock rights, and so let them expire. The BTS staff of about ten permanent employees reduced investor uncertainty through explanatory media: advertisements, pamphlets, and letters. Articles in the Bell Quarterly regularly discussed the extensive, time-consuming

\footnotetext{
89. FCC, Investigation of the Telephone Industry, 442-446.

90. Ibid., 444.

91. Ibid., 448.

92. Ibid., 442 .

93. Ibid., calculated from information on Table 72, 447.

94. Ibid., 451.
} 
efforts made to contact rights-holders individually and then walk them through the process of rights' exercise. ${ }^{95}$ The fact that AT\&T was prepared to accept these costs shows the value the firm management placed on this activity. The actual processing of rights was left to AT\&T's New York's treasury department. Although normally numbering about two hundred employees, rights offering were timed each year so that four hundred summer employees, usually college students on vacation, could complete this work. The new issues were announced during the spring. Deadlines for subscribing to new issues generally were in early June. Most of the administrative work associated with the registration of new ownership interest was completed by August. ${ }^{96}$

BTS reduced transaction costs by accumulating large parcels of rights to facilitate the economical buying of shares in the market. In accumulating orders, BTS achieved economies of scale that reduced average transaction costs and increased the scope of the potential subscriber base. Most individual investor rights during the 1920s were transacted in small lots of one to five shares, quantities normally not economical for brokers to handle. Additionally, the exercise of these rights was allowed to proceed through cash installments paid over eight months, increasing the ability of those of limited means to accumulate enough capital for share purchase. ${ }^{97}$ Thus, BTS's operations benefitted the Bell System by securing new financing while simultaneously providing economic benefits to its small shareholders.

AT\&T's emphasis on ensuring that shareholders participate in preemptive rights' offerings was unusual because its purpose was both to supply capital to the firm and to promote the stock's value for existing holders. In their contemporaneous study of U.S. stock ownership, Berle and Means noted that stock rights offerings often served the purpose of diluting stock ownership and hastening the separation of ownership and control of corporations. However, while criticizing the role of rights ownership in the dilution of existing stockholder control, these authors repeatedly cited AT\&T as an exception to the general trend. They noted that contrary to the experience of most corporations, by issuing rights AT\&T "enhances the value of the outstanding stock. It is in fact an automatic device preventing dilution of assets."98 As 1920s economist Harvard University Professor William Z. Ripley wrote, "the right of shareholders in a corporation to participate to their advantage in all subsequent issues of shares ... is the very

95. Blair-Smith, "1924 Stock Issue”; Blair-Smith, "1926 Stock Issue.”

96. Blair-Smith, "1924 Stock Issue”; Blair-Smith, "1926 Stock Issue”; BlairSmith, "1928 Stock Offer”; Blair-Smith, "1930 Stock Offer."

97. NYSE, Stock Issues for AT\&T, 1922, Box 119, Folder a-5802, NYSE Archives.

98. Berle and Means, Modern Corporation, 134. 
essence of corporate democracy.” Ripley generally saw firms' efforts to sell stock to customers as attempted robbery, unlike "great corporations like American Telephone, which treats the matter (the existence of customer investors) from the high standpoint of a trustee."99

BTS worked out procedures for coordinating the activities of the regional operating subsidiaries in planning the collection of exercised rights, and it was successful in increasing the percentage of rights exercised. ${ }^{100}$ The publicity efforts by a staid dividend-paying utility proved effective in attracting capital from risk-averse investors seeking other conservative investments to replace the massive retirement of Liberty Bonds. Perhaps as important, however, is that BTS increased the liquidity of these rights. At the first offering in 1921, five shares were offered for every share held, and purchase of the shares could take place in installments payable over four months. ${ }^{101}$ In 1924 fractional share warrants were offered for the first time; though only full shares were issued, rights became tradable so that they could be bundled by secondary purchasers and exchanged for new shares. ${ }^{102}$ In 1926 the number of rights assigned to each share increased to six. ${ }^{103}$

BTS created a significant number of middle-class shareholders through its installment sales program; through its rights offerings, it also raised a substantial amount of capital for the Bell System. BTS also proved profitable for AT\&T. Capitalized initially at \$1 million, management believed that the new financing subsidiary would operate at break-even. ${ }^{104}$ BTS received dividends and earned profits trading AT\&T securities; from 1921 through 1935, BTS received dividends of $\$ 2.9$ million on the common stock it held to support its stock subscriptions. It earned another $\$ 2.5$ million from trading AT\&T stock and \$0.5 million in rights. ${ }^{105}$ Interest and dividend income were also earned from the investment of surplus funds. ${ }^{106}$

BTS's expenses were negligible. Enlisting operating company personnel as a sales force facilitated the integration of the retail share distribution. This kept direct transactions costs low by eliminating the middleman between the firm and the customer-shareholder.

99. Ripley, Main Street and Wall Street, 38 and 344.

100. In the 1924 stock issue, 14 percent of the rights to purchase one share for each five shares owned went unexercised; in the next rights offering in 1926, the ratio of rights not subscribed fell to 6 percent, reflecting in part the effect of a more robust public information drive. Blair-Smith, "1926 Stock Issue."

101. NYSE, Stock Issues for AT\&T, 1921, Box 22, Folder a-2503, NYSE Archives.

102. Ibid., 1924, Box 130, Folder a-6238 and Folder a-6371, NYSE Archives.

103. Ibid., 1926, Box 142, Folder a-7160, NYSE Archives.

104. AT\&T, Annual Report 1922, 15.

105. Special Investigation Docket No. 1, "Report on Bell Telephone Securities" Box 25, Exhibit 250, FCC, National Archives.

106. Ibid., n.p., schedule 8, FCC, National Archives. 
Employees were routinely paid \$1 for each new customer order, ${ }^{107}$ substantially less than the earlier 1 percent commission paid to Kidder, Peabody. ${ }^{108}$

The employee sales force also complemented the Bell System's public relations activities. In 1912 AT\&T formed a bureau in its statistics division, which provided information on "the trend of public opinion and the drift of legislation."109 With increasing frequency after World War I, Bell management pursued a public relations campaign that portrayed the firm as one dedicated to public service and that promoted "democratic capitalism." 110 The involvement of local office staff in the sales effort served to enhance a spirit of pride within employees while creating a "folksy" image with the public.

Attempting to capitalize on a spirit of national pride engendered by the recent war, the advertising was also used to align the interests of the company with those of American society as a whole: what was good for Bell was good for America. Potential customers were reminded in a 1924 offering circular that "the investor in the securities of this Company purchases an interest in the telephone business of the entire country"; a 1926 circular went even further, stating that BTS served "the common good"111 (figure 3).

The firm trumpeted the growth of its ownership base in its annual reports (figure 4) and company advertising, although it was selective in how the material was presented. ${ }^{112}$ For example, at a 1926 Bell conference, attendee Yale Professor Irving Eisher tried to pin management down on how many shares were owned by the "typical owner," but he was evasively answered by BTS President Houston, who stated: "The stock of the System is controlled by those who own one hundred shares or less."113 Unfortunately, moments later,

107. For example, in 1922, a letter from the BTS to all Bell employees explained that a $\$ 1$ commission would be paid for each share of a \$25 million offering of preferred stock solicited by employees. Houston, "Letter to All Employees," June 24, 1922, File 2180A, Loc. 540, Audio Room 04, AT\&T Archives.

108. Indeed, the commission sometimes exceeded 1 percent. In a memo recording of Kidder, Peabody charges for 1921, the commission paid for shares averaged 1.5 percent. Kidder, Peabody \& Company, unsigned memo, "Costs Incurred in Respect to Publicity Campaign Conducted for AT\&T, to December 31, 1921,” File 2180A, Loc. 540, Audio Room 04, AT\&T Archives.

109. Letter from Walter S. Allen to Nathan C. Kingsbury, 1912, n.d., Box 20, 125-07-02-01, AT\&T Archives.

110. Marchand, Corporate Soul, 74.

111. NYSE, Stock Issues for AT\&T, 1924, Box 130, Folder a-6238 and Folder a-6371, NYSE Archives; AT\&T, BTS advertising circular, 1926, AT\&T advertising copy, File 2180A, Loc. 540, AT\&T Archives.

112. Marchand, Corporate Soul, chap 2.

113. Houston, "Talk at Bell Education Conference," 347. 


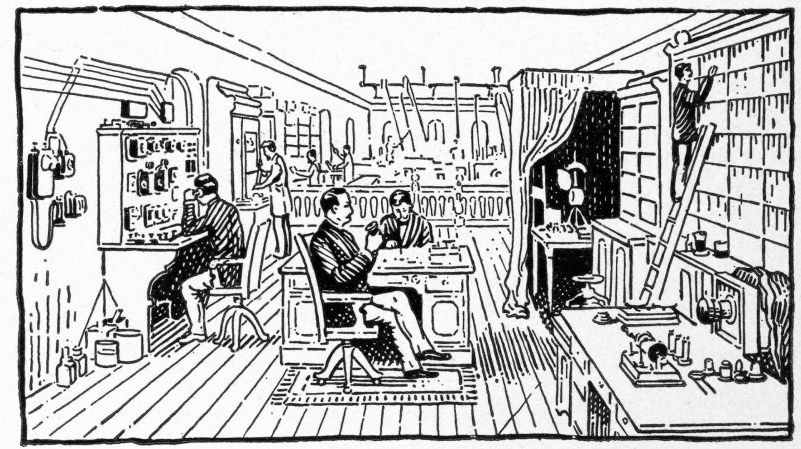

For the common good

TN THE eighties, scientific research and experimentation in telephony were conducted in the workshop illustrated above with a mere handful of workers. Today they are carried on in a modern thirteen-story building in New York City - the home of the Bell. Telephone Laboratories, Inc. Here over 3,500 people - trained scientists, engineers and their assistants - seek untiringly for scientific means of bringing the nation's telephone service still nearer to perfection.

It is this never ceasing endeavor that has in a half century brought telephone service to its present extent and efficiency-from one telephone in 1876 to over $17,000,000$ today, carrying 73,600,000 messages daily; from a few yards of wire to a wire mileage today of $53,600,000$; from facilities costing a few dollars to a present book cost of over $\$ 2,600,000,000$.

A nation-wide plant and its widespread service underlie Bell System securities.

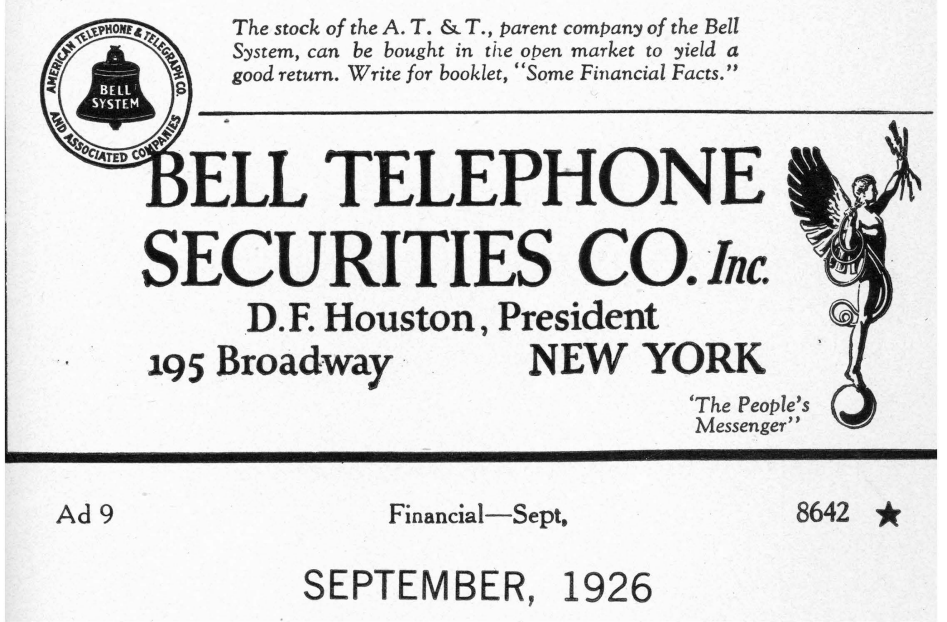

Figure 3 Bell Telephone Securities Co. advertising circular.

Source: 1926 AT\&T advertising circular. 


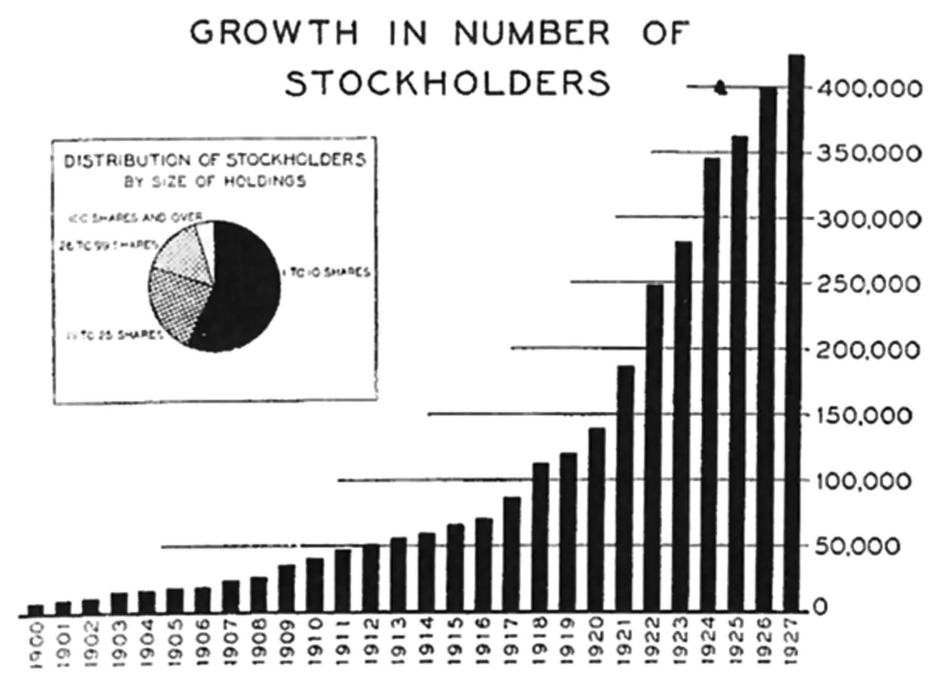

Figure 4 Bell stockholders, 1900-1927.

Source: AT\&T, Annual Report of the Directors of the American Telephone and Telegraph Company, 1927.

Bell's treasurer added that only eighteen thousand shareholders out of a total of four hundred thousand were needed to achieve a majority, indicating that some of these shareholders held a disproportionately large number of shares. This reality was echoed by Nestor Danielian, another critic, who noted in 1939 that while emphasizing no shareholder owned even 1 percent of its stock, AT\&T did not mention that nearly 50 percent of the firm was held by only 5 percent of the owners. ${ }^{114}$

Meanwhile, Bell employees at all levels were encouraged to become AT\&T stockholders themselves. The employee stock-ownership plan was part of a larger effort to encourage employees to become thrifty, miniature capitalists. In addition to the stock-ownership plan, the company sponsored savings plans and life insurance with automatic pay withdrawals. Budget books were distributed free to all employees, and firm magazines contained articles on topics such as investing and insurance. As a national firm, increasing employee ownership helped create a loyal employee base and a substantial, geographically dispersed, middle-class constituency for the firm. These owners helped to foster the image of the Bell System as a group of ordinary workingclass people-linesmen, operators, and so on-working to better their fellow citizens, and not just as a faceless, monolithic corporation. Due to their large numbers-excluding Western Electric, Bell employees

114. Danielian, AT\&T: The Story of Industrial Conquest. 
numbered just under 300,000 in 1925 and nearly 325,000 in 1930115_ the firm's employees constituted a sizeable public relations presence as well as a potential shareholder base.

Promoting broader geographic ownership among both customers and employees helped to create a community of investors that identified strongly with the policies of the heavily regulated utility. As stated in company promotional material, the firm wished to redefine its relationship with the public from merely "customers" to "partners." 116 To this end, the direct sales program was eventually offered in forty-one states, ${ }^{117}$ although it was most active in the Midwest and Southwest.

BTS used pamphlets, newspapers, magazine advertisements, letters, and direct representative consultation to distribute investment information. The intensity of such efforts varied among regions. BTS additionally sought to build up broader communities of interest for the regional operating companies by reducing information and transaction costs in the sale of subsidiary preferred stock issues, a significant funding source for the regional Bell operating companies. As in the case of the parent company's common equity sales, BTS worked with the regional operating companies to advertise new stock issues and to develop organizational mechanisms to accept subscriptions and to distribute shares. ${ }^{118}$

Concurrently, BTS played an active role in the liquidation of minority interests in Bell subsidiary common stock through exchanges with the equity of the parent company. Many of the subsidiary operating companies had originally been operated as franchises during the Bell System's formative years as a means of conserving financial capital. As the firm prospered, it gradually repurchased shares from the original franchisees, but substantial balances still remained

115. AT\&T Annual Report 1925, 32; AT\&T Annual Report 1930, 26.

116. “Dear Sir” letter, 1921, Bell Telephone Securities, File 2180A, Loc. 540, Audio Room 04, AT\&T Archives.

117. Bell Telephone Securities, Annual Report of the Bell Telephone Securities Company (hereafter, Annual Report) 1929. New England states did not participateprobably because the shares were already widely held in these states-and the participation of a few other states were precluded by "blue sky laws."

118. Bell Telephone Securities assisted in selling preferred stock for Southwestern Bell (1922, 121,656 shares), Wisconsin Telephone (1922, 50,000 shares), Chesapeake and Potomac Telephone (1922, 30,000 shares), New York Telephone (1922, 250,000 shares) (see AT\&T, Annual Report 1922, 16); Bell Telephone of Pennsylvania (1923, 200,000 shares) (see AT\&T, Annual Report 1923, 34); Diamond State Telephone (1925, 5,000 shares) (see AT\&T, Annual Report 1925, 29); and Northwestern Bell Telephone (1926, 50,000 shares) (see AT\&T, Annual Report 1926, 29). BTS also promoted the sale of an issue of $\$ 100$ million convertible debentures during 1929 (see Bell Telephone Securities, Annual Report 1929). 
outstanding in a few cases as late as the 1920s. During that decade, it traded AT\&T stock for shares in New England Telephone (acquired 8,906 common shares), Pacific Telephone and Telegraph (acquired 31,670 common shares), and Western Electric (acquired 21,620 common shares). ${ }^{119}$

\section{Impact of BTS's Operation}

Bell management launched BTS with the goals of raising capital for expansion; broadening ownership (particularly outside of the Northeast) of AT\&T stock; and creating a positive, popular perception of the firm. Operations that supported the market price of AT\&T stock had a favorable impact on raising equity capital through rights offerings and bond conversions, the major sources of new equity capital for the firm. Its stock price steadily advanced from a low of $\$ 92.13$ in 1920 to a high of $\$ 310.25$ in 1929, an increase of 331 percent. Between 1921 and 1930, there were six rights offerings, which distributed an additional 9.6 million shares. With the exception of the $\$ 2.8125$ per share premium realized in the disappointing 1921 issue (which occurred three months before the formation of BTS), each flotation had average premiums that ranged from $\$ 18.75$ (1922) to $\$ 123$ (1930). By the end of 1930, the combination of rights and conversion issuances of 13.6 million shares represented about 61 percent of the 18.7 million shares outstanding. The exercise of convertible bond rights added an additional 4.2 million shares. ${ }^{120}$

BTS's direct and installment stock sales broadened the shareholder base. Consistent with the firm's initial plan for the new subsidiary, about 85 percent of its activity pertained to small stockholders. ${ }^{121}$ The number of shareowners increased from 40,000 in 1910; to 139,000 in 1920; and to 650,000 in $1935 .^{122}$ In addition, BTS redistributed another 600,000 shares through the employee stock option plan from 1921 through 1933. ${ }^{123}$

Demographic and geographic diversity of ownership was also largely achieved. The impact of the small investor was reflected

119. Bell Telephone Securities, Annual Report 1929, 66-68.

120. The information is drawn from schedules 73, 74, and 75 in FCC, Proposed Report, 514-516. Some of this information was reproduced in the final report of the FCC in 1939. The total number of BTS shares distributed is reported in FCC, Proposed Report, 18.

121. Ibid., 30.

122. AT\&T, Annual Report 1910, 15; AT\&T, Annual Report 1935, 28, respectively.

123. Calculated from FCC, Proposed Report, 18-19. For employee ownership at AT\&T, see National Industrial Conference Board, Employee Stock Purchase Plans, $37,39,110-111$. 
in the decreased size of the average ownership position, dropping from seventy-six shares in 1900 to twenty-five in $1925 .{ }^{124}$ No individual owned more than one-fifth of 1 percent of the firm's equity, and more than 50 percent of the stockholders held ten or fewer shares. ${ }^{125}$ Recall, however, that this overlooks the fact that only eighteen thousand shareholders, out of a total of four hundred thousand, owned a sufficient number of shares to constitute a majority, and this ownership segment had holdings far in excess of one hundred shares. ${ }^{126}$ BTS also succeeded in broadening the distribution of its stock beyond the Northeast. There were stockholders in every state of the Union and eighty foreign countries. Twelve states had more than ten thousand stockholders each; twenty-two states had more than five thousand stockholders; no state had less than five hundred stockholders. Management's success in geographically expanding the Bell System's ownership base is clearly seen in figures 5 and 6 . Figure 5 shows the map of the number of shareholders per one thousand of population in 1929; although large concentrations of ownership were still found in the Northeast, two western states (California and Colorado) had ownership rates at the same level

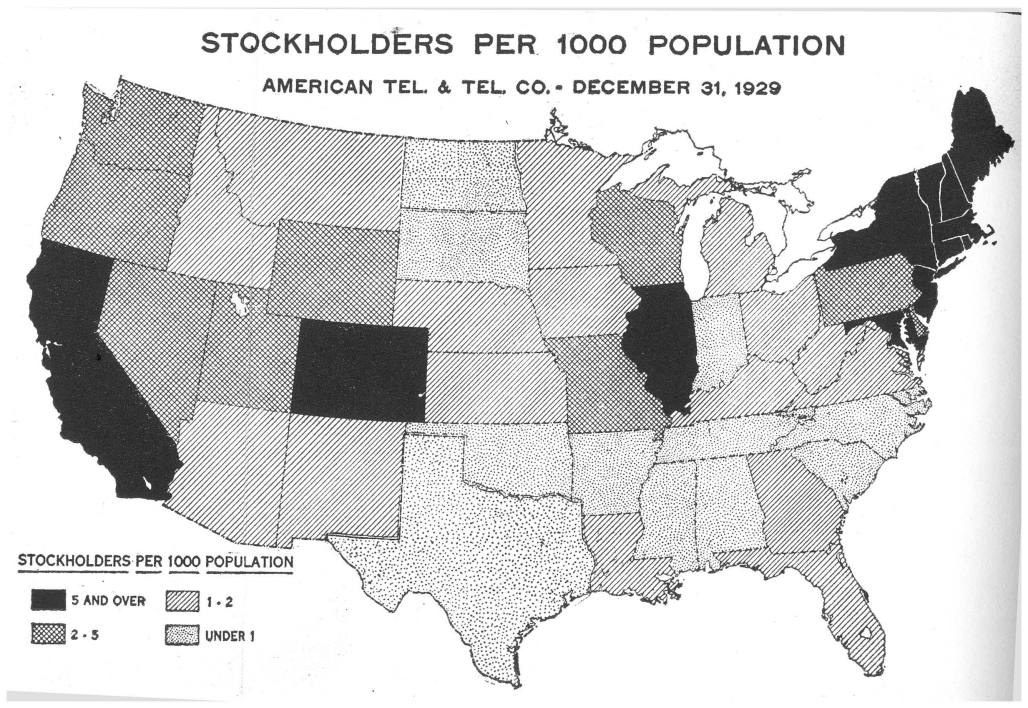

Figure 5 Bell stockholders by state, 1929.

Source: Bell Telephone Securities, Annual Report of the Bell Telephone Securities Company, 1929.

124. AT\&T, Annual Report 1925, 21.

125. AT\&T, Annual Report 1927, 19.

126. Houston, "Talk at Bell Education Conference," 347. 


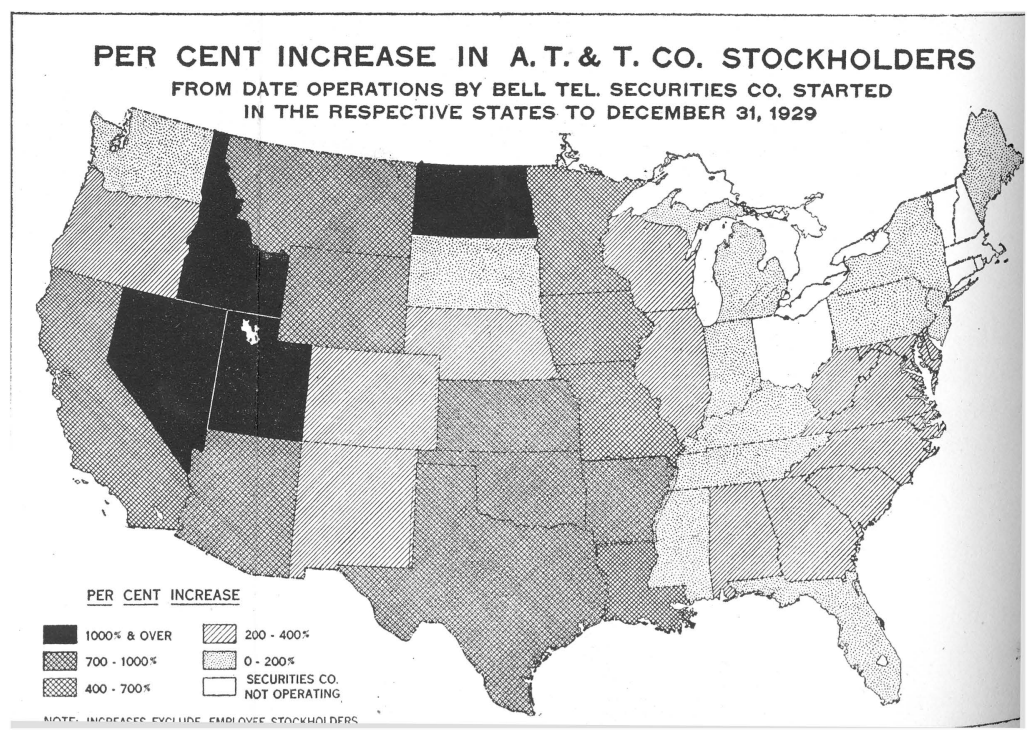

Figure 6 Percentage increase in Bell stockholders by state, 1921-1929.

Source: Bell Telephone Securities, Annual Report of the Bell Telephone Securities Company, 1929.

(five or more shareholders per one thousand residents). Shareholders were now to be found in every state.

The second map (figure 6) shows the percentage gain in Bell stock ownership from the time BTS began its operations in the state until the end of 1929 and highlights its impact in expanding geographic dispersion. States in the south (Texas, Louisiana) and west (California, Idaho, Minnesota, Nevada, Utah, Wyoming) experienced increases in stockholders of between 700 percent and 1,000 percent.

Beyond geographic diversity, the Bell System succeeded in creating a shareholder class that crossed economic, cultural, and social boundaries (figure 7). A study of purchasers of Bell System stock in 1925 found that shareholders came from all fields; the five largest occupations identified from the more than two hundred thousand individual purchasers were 3 percent each executives and salesmen, 11 percent clerks, 16 percent laborers, and 17 percent housewives. ${ }^{127}$ Women in general constituted a significant proportion of stockholders; in 1929, for example, women stockholders were said to outnumber men by eighty-four thousand. ${ }^{128}$

127. Houston, "Some Aspects of the Telephone Business and Its Financing," 10.

128. AT\&T, Annual Report 1929, 19. 


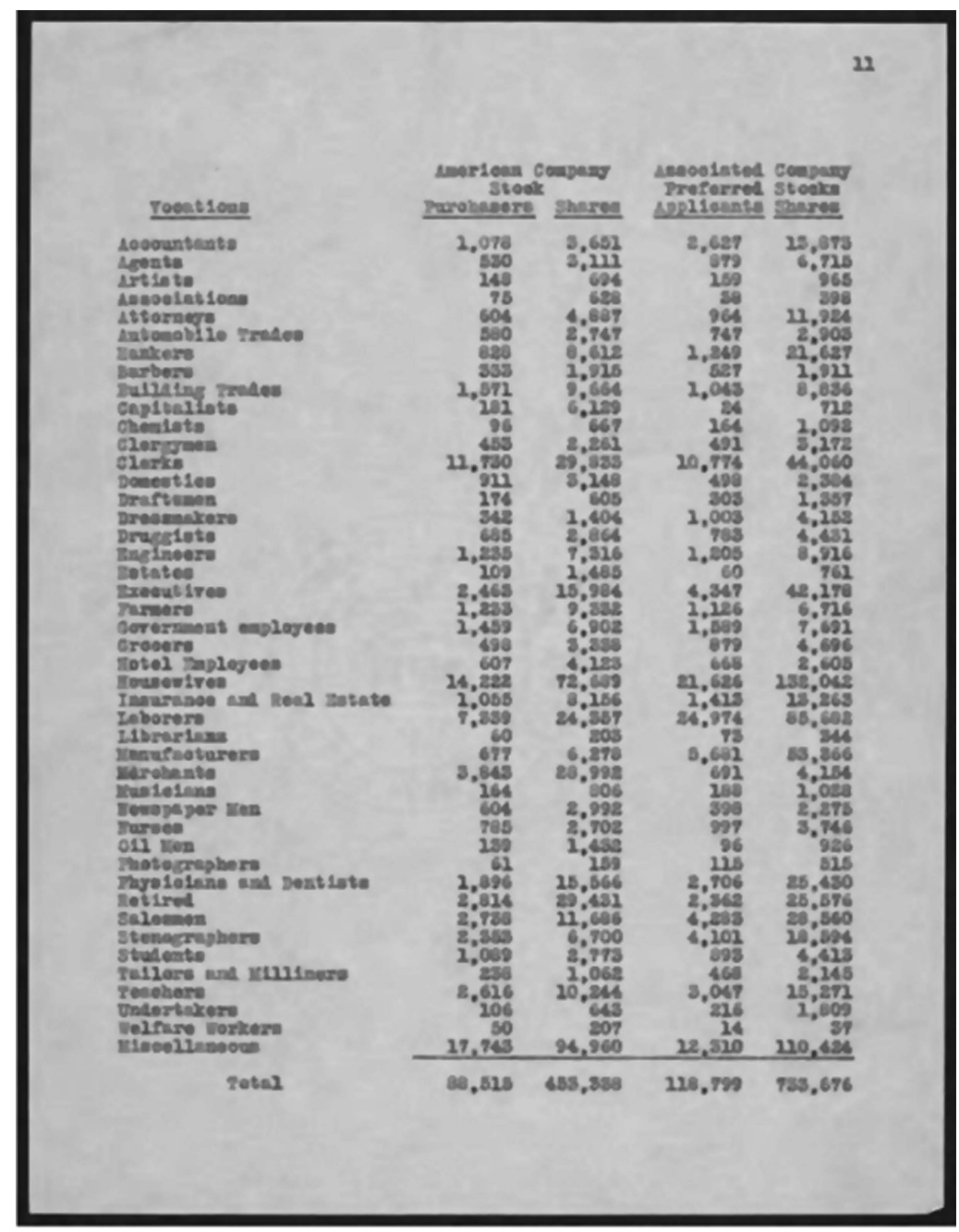

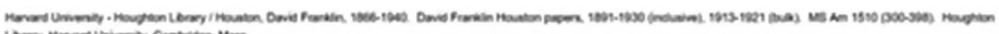

Figure 7 AT\&T subscribing shareholders by occupation, 1925.

Source: David Franklin Houston Papers, Item 311, Houghton Library, Call number MS Am 1510, Harvard University, Cambridge, MA.

BTS's activity slowed as the Depression progressed. ${ }^{129}$ The decade's apex in system building was reached in 1930, when total system plant slightly exceeded $\$ 3$ billion before it entered a period

129. It participated in the conversion of $\$ 132$ million of the 1929 convertible bond offering, or about 60 percent of the issue of \$219 million. Blair-Smith, "1929 Convertible Bond Offer." It was also active in the floatation of the 1930 rights offering of \$257 million par value common shares of AT\&T. Blair-Smith, "1930 Stock Offer." 
of gradual contraction. Firm revenues exceeded $\$ 1$ billion in 1930, but they steadily fell back to about $\$ 850$ million in $1933 .{ }^{130}$

\section{The Vision's Legacy}

Like many other firms, BTS did not survive the Great Depression, though not because of business failure. Rather, the circumstanceseconomic and political-that contributed to the success of BTS disappeared, and new costs in the form of increased regulatory scrutiny and burdens appeared. Furthermore, BTS had achieved its strategic purposes. It had facilitated the raising of large amounts of financial capital through rights offerings and debt conversion. It had also built a constituency of small, geographically dispersed stockholders who absorbed about 10 percent of the firm's total equity. If the firm wished to continue to expand this constituency, there now existed retail firms to service such investors. However, the need no longer existed.

In the aftermath of the Great Depression, stock subscriptions evaporated, as reflected in a lack of share growth subsequent to 1931. A steady increase in the number of shares outstanding during the 1920s moderated significantly in 1931, and then flattened out after 1935 (figure 8).

Along with the demand for stock drying up, the Depression eliminated trading gains for BTS. The Bell System became subject to everincreasing, intense scrutiny from federal regulators. AT\&T's relationship with the Securities and Exchange Commission (SEC) became more

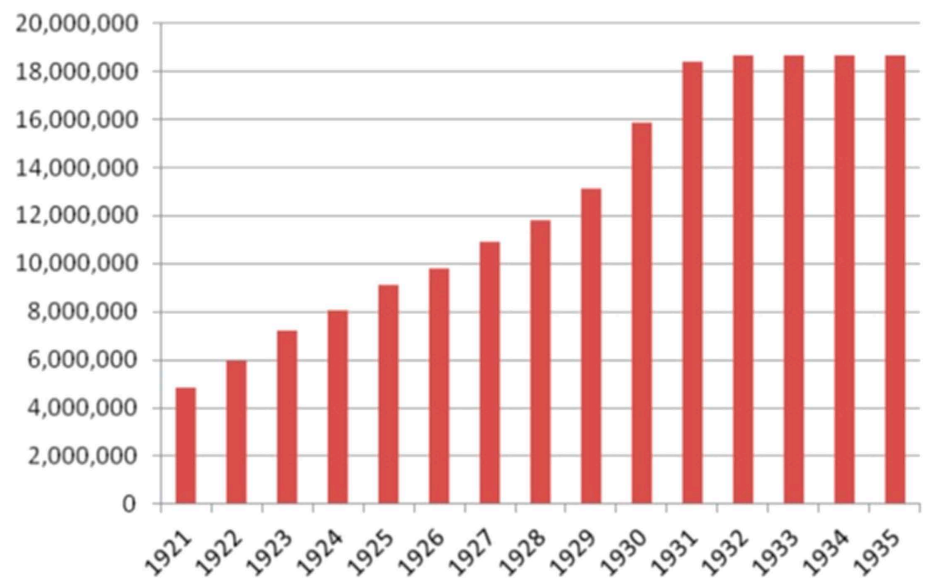

Figure 8 AT\&T, number of shares outstanding, 1921-1935.

Source: FCC, Investigation of the Telephone Industry in the United States, Table 83, 508.

130. AT\&T, Annual Report 1933, 10. 
complex as, via BTS, the firm maintained its status as either a broker or dealer in several states. The decision to dissolve BTS came in 1936, partially in response to the forthcoming Revenue Act of 1936, with its proposed 15 percent tax imposed on dividends received by the parent enterprise from controlled entities such as BTS. ${ }^{131}$ The likelihood of a future revival of BTS was effectively cut off by a highly critical report by the staff of the FCC, which in 1934 had become the most recent federal regulatory agency for the industry. The federal regulators were critical of the BTS arrangement, believing that it was a challengeable subterfuge that allowed the parent to deal in its own shares. Because BTS had achieved its purposes, Bell management did not feel the need to contest the FCC's contention, and so the BTS was dismantled.

\section{Conclusion}

Bell Systems' decisions first to incorporate securities services and then later to abandon this commitment responded to several developments. Firm management appears to have recognized that synchronous building up of the firm's political and financial capital was economically feasible and beneficial. It accomplished these ends through a national company that operated regionally. Through sales to their customers and employees, the firm established a geographically and economically diverse ownership base as a means of raising capital; the concurrent growth of investor democracy served to address challenges in its sociopolitical environment. The firm increased the sale of common equity to finance expansion principally through periodic rights offerings the conversion of debt. The absence of an existing national brokerage, which could economically provide these services, gave the impetus for the firm to attempt to meet part of its stock financing objectives internally. Although the changing business environment created opportunities for institutional evolution, transaction and social cost considerations imposed economic discipline over the process of organizational and functional redefinition.

As a financing vehicle, BTS achieved important goals. First, it supported the market price of Bell shares through share repurchases, which ensured the success of the firm in its rights offerings and bond conversions. Through its purchase of large block of shares in advance of the conversion of installment sales to stock ownership, BTS was a major factor in ensuring the liquidity of AT\&T

131. Special Investigation Docket No. 1, 1936, “C. P. Cooper, Vice President from J. F. Behan, Treasurer,” August 10, 1936, Record Group 173, Box 25, Exhibit 283, FCC, National Archives. 
stock as well as in providing share price support. BTS's efforts to expand the exercise of rights' offerings ensured that existing shareholders would not have their ownership diluted, while providing a significant, and predictable, source of funds for necessary capital expansion.

Second, BTS's market support activity had a positive influence on the cost of equity capital. These financing activities, taken together, helped to reduce risk to the firm by placing greater reliance on equity over debt finance. Reducing financial risk simultaneously counterbalanced the increased operating risk of the company associated with its significant investment in plant to support its economic expansion. In this way, the creation of BTS fit in with the firm's overall strategic vision. Virtually all of the firm's policies related to such activities as technology, policy, and finance sought to eliminate dangers to the continuing functionality of the complex network that the firm had created. BTS's development of a reliable source of equity capital reduced financial risks; the constituency it created and public image it promoted hedged against political and regulatory encroachments on the firm's operations.

Geographic dispersion of ownership had the salutary effect, from the firm's perspective, of increasing the number of individuals who strongly identified with the firm and its programs as a consequence of investment interest in states where ownership levels had previously been low. The expanded ownership base helped to build political leverage, particularly at the state level, a major focus of regulatory activity. The political economy, then, influenced the firm to view financing activities not just in light of the firm's capital needs but also as a sociopolitical activity that would tie together the interests of the firm and the public. At the same time, increased stock ownership among employees created a loyal, as well as a vocal and national, constituency. Like the firm's extensive advertising and public relations efforts, Bell management believed the new connections based on stock ownership could favorably influence public opinion by making more concentric the economic interests of a growing body of middle-class savers with the telecommunications giant. The Bell System was an important part of creating and defining investor democracy in America, a term that was understood to mean many things to many people-a way to protect America's capitalist tradition, a way to spread the benefits of American capitalism to the average man, and a way to strengthen middle-class ties to American democracy and away from radical, foreign, or socialist ideas. The firm employed investment education as well as firmspecific financing information as a persuasive tool: to convince investors (who were often customers) of the benefits of purchasing 
AT\&T shares. The firm's educational efforts also sought to influence social (and the voting public's) views on big business. Through image management and creation of a public constituency, AT\&T sought to ward off the increasing power of regulators.

Ultimately, the effort to expand the firm's ownership base ended in the 1930s when economic and regulatory factors converged to force AT\&T to close down Bell Telephone Securities. The decade-long contraction of economic and financial markets, which became known as the Great Depression, temporarily ended the expansion of stock ownership. Mounting regulatory and tax costs proved excessive. Without customers willing or able to become investors in the Bell System, expansion of the firm's political constituency slowed significantly. With the creation of the Securities and Exchange Commission, management's hope that BTS would avoid regulation proved unfounded. Finally, however, the dissolution of BTS reflected the fact that the entity had already secured the positive objectives of its formation. The creation of BTS allowed Bell to circumvent market imperfections, which prevented national distribution of its shares through existing channels. Through its rights offerings, BTS facilitated a substantial source of new firm capital. Through the activities of regional Bell personnel acting as BTS agents, AT\&T underwent a transformation of its ownership base both in sheer numbers and in geographic distribution, creating a new political constituency of middle-class American customers and employees of the telephone system. This ownership description helped define a positive image for the firm, and possibly was helpful in delaying regulatory encroachment. The creation of a shareholder constituency in the 1920s and 1930s was certainly a factor in prolonging the firm's oligopolistic control of the telephone industry; that is, until the break-up of AT\&T in 1984.

AT\&T's strategy with respect to the Bell Telephone Securities is not fully comprehensible through the evaluation of economic or social costs taken individually. Through analysis of BTS's archival materials, we found how one firm's financing decisions were based on a broad, complex, and interrelated conception of economic, social, and political factors. Operating nationally across a continent with regional differences added a level of complexity. By enlisting local personnel as a sales force, AT\&T was able to leverage its large regional presence to facilitate the spread of investor democracy. The regions were seen as targets for expansion of share ownership in areas without a strong shareholder base. In this way, BTS successfully served as a national entity that met regional financing needs. Simultaneously, BTS operations emphasized the national, progressive role of the telephone system, and helped individuals-whatever region they dwelt in-identify as part of this larger enterprise. Bell management actions 
relating to financing and BTS constituted a coordinated response to complex external factors such as technology, and a combination of shifting markets, society, and the national political economy.

\section{Bibliography of Works Cited}

\section{Books}

Adams, Stephen B., and Orville R. Butler. Manufacturing the Future: A History of Western Electric. Cambridge: Cambridge University Press, 1999.

Berle, Adolf A., and Gardiner C. Means. The Modern Corporation \& Private Property. 1933. Reprint, New Brunswick, NJ Transaction Publishers, 1968.

Bonbright, James C., and Gardiner C. Means. The Holding Company: Its Public Significance and Its Regulation. New York: McGraw-Hill, 1932.

Carosso, Vincent P. Investment Banking in America: A History. Harvard Studies in Business History. Cambridge, MA: Harvard University Press, 1970.

- More than a Century of Investment Banking: The Kidder, Peabody and Company Story. New York: McGraw-Hill Book Co., 1979.

- The Morgans: Private International Bankers, 1854-1913. Harvard Studies in Business History. Cambridge, MA: Harvard University Press, 1987.

Carver, Thomas N. Recollections of an Unplanned Life. Los Angeles: Ward Ritchie Press. 1949.

The Present Economic Revolution in the United States. Boston: Little, Brown and Company, 1926.

Chandler, Alfred D., and Stephen Salisbury. Pierre Du Pont and the Making of the Modern Corporation. New York: Harper \& Row, 1971.

Chandler, Alfred D., and Stephen Salisbury, and Richard S. Tedlow. The Coming of Managerial Capitalism. Homewood, IL: R. D. Irwin, 1985.

Danielian, Nestor. R. AT\&T: The Story of Industrial Conquest. New York: Vanguard Press, 1939.

Federal Communications Commission. Proposed Report: Telephone Investigation. Washington, DC: Government Printing Office, 1938.

- Investigation of the Telephone Industry of the United States. Washington, DC: Government Printing Office, 1939.

Gage, Beverly. The Day Wall Street Exploded: The Story of America in Its First Age of Terror. New York: Oxford University Press, 2009.

Galambos, Louis, and Joseph Pratt. The Rise of the Corporate Commonwealth: U.S. Business and Public Policy in the Twentieth Century. New York: Basic Books, 1988.

Garnet, Robert W. The Telephone Enterprise: The Evolution of the Bell System's Horizontal Structure, 1876-1909. Baltimore, MD: The Johns Hopkins University Press, 1985.

Gertner, Jon. The Idea Factory: Bell Labs and the Grand Age of American Innovation. New York: Penguin, 2012.

Green, Venus. Race on the Line: Gender, Labor and Technology in the Bell System, 1880-1980. Durham, NC: Duke University Press, 2001. 
Hausman, William, Peter Hertner, and Mira Wilkins. Global Electrification, Multinational Enterprise and International Finance in the History of Light and Power, 1878-2007 Cambridge: Cambridge University Press, 2008.

Hawley, E. W. The Great War and the Search for Modern Order: A History of the American People and Institutions, 1917-1933. New York: St. Martin's Press, 1979.

Hyman, Louis. 2011. Debtor Nation: The History of America in the Red. Princeton, NJ: Princeton University Press, 2011.

John, Richard R. Network Nation: Inventing American Telecommunications. Cambridge, MA: Belknap Press of Harvard University Press, 2010.

Jones, Christopher. Routes of Power. Cambridge, MA: Harvard University Press, 2014.

Lang, Harry G. A Phone of Our Own: The Deaf Insurrection Against Ma Bell. Washington, DC: Gallaudet University Press, 2000.

Larson, John. Bonds of Enterprise: John Murray Forbes and Western Development in America's Railway Age. Cambridge, MA: Harvard University Press, 1964.

Latzke, Paul. A Fight with an Octopus. Chicago: Telephony Publishing Company, 1906.

Lipartito, Kenneth. The Bell System and Regional Business: The Telephone in the South, 1877-1920. Baltimore, MD: The Johns Hopkins University Press, 1989.

Levy, Jonathan. Freaks of Fortune. Cambridge, MA: Harvard University Press, 2012.

MacDougall, Robert. The People's Telephone: The Political Economy of the Telephone in the Gilded Age. Philadelphia: University of Pennsylvania Press, 2013.

Marchand, Roland. Creating the Corporate Soul: The Rise of Public Relations and Corporate Imagery in American Big Business. Berkeley: University of California Press, 1998.

- Advertising the American Dream: Making Way for Modernity, 19201940. Berkeley: University of California Press, 1985.

Markham, Jerry W. A Financial History of the United States, vol. 2. Armonk, NY: M. E. Sharpe, 2002.

McCraw, Thomas K. Prophets of Regulation. Cambridge, MA: Harvard University Press, 1984.

Miller, George H. Railroads and the Granger Laws. Madison: University of Wisconsin Press, 1971.

Mueller, Milton L., Jr. Universal Service: Competition, Interconnection and Monopoly in the Making of the American Telephone System. Cambridge, MA: MIT Press, 1997.

Murray, Robert K. Red Scare: A Study of National Hysteria, 1919-1920. Minneapolis: University of Minnesota Press, 1955.

Ott, Julia C. When Wall Street Met Main Street: The Quest for an Investors' Democracy. Cambridge, MA: Harvard University Press, 2011.

Perkins, Edwin J. Wall Street to Main Street: Charles Merrill and Middle Class Investors. New York: Cambridge University Press, 1999. 
Reich, Leonard S. The Making of American Industrial Research, Science and Business at GE and Bell. Cambridge: Cambridge University Press, 1985.

Ripley, William Z. Main Street and Wall Street. Boston: Little, Brown, 1927.

Rorty, Malcolm C. Some Current Economic Problems. Chicago: A. W. Shaw Co., 1922.

Russel, F. A City in Terror: Calvin Coolidge and the 1919 Boston Police Strike. 1875. Reprint, Boston: Beacon Press, 1930.

Skowronek, Stephen. The New American State: The Expansion of National Administrative Capacities, 1877-1920. Cambridge: Cambridge University Press, 1982.

Smith, Edgar L. Common Stocks as Long Term Investments. Kila, MT: Kessinger Publishing Company, 1922.

Smith, George D. The Anatomy of a Business Strategy: Bell, Western Electric and the Origins of the American Telephone Industry. Baltimore, MD: The Johns Hopkins University Press, 1985.

Stehman, J. Warren. The Financial History of the American Telephone and Telegraph Company. Boston: Houghton, Mifflin \& Co., 1925.

Symkay, E. W. The National Association of Railroad and Utility Commissioners as the Originators and Promoters of Public Policy for the Public Utilities. Milwaukee: University of Wisconsin, Milwaukee, 1955.

Wasserman, Neil H. From Invention to Innovation: Long-Distance Telephone Transmission at the Turn of the Century. Baltimore, MD: The Johns Hopkins University, 1985.

Wiebe, Robert. Search for Order, 1877-1920. New York: Farrar, Straus and Giroux. Articles, Chapters, and Reports

AT\&T. Annual Report of the Directors of the American Telephone and Telegraph Company. Boston: privately printed, 1900.

- Annual Report of the Directors of the American Telephone and Telegraph Company, Inc. Boston: privately printed, 1908.

- Annual Report of the Directors of the American Telephone and Telegraph Company. New York: privately printed, 1910.

- Annual Report of the Directors of the American Telephone and Telegraph Company. New York: privately printed, 1913.

- Annual Report of the Directors of the American Telephone and Telegraph Company. New York: privately printed, 1916.

- Annual Report of the Directors of the American Telephone and Telegraph Company. New York: privately printed, 1922.

- Annual Report of the Directors of the American Telephone and Telegraph Company. New York: privately printed, 1925.

- Annual Report of the Directors of the American Telephone and Telegraph Company. New York: privately printed, 1927.

- Annual Report of the Directors of the American Telephone and Telegraph Company. New York: privately printed, 1929.

- Annual Report of the Directors of the American Telephone and Telegraph Company. New York: privately printed, 1930. 
Annual Report of the Directors of the American Telephone and Telegraph Company. New York: privately printed, 1933.

- Annual Report of the Directors of the American Telephone and Telegraph Company. New York: privately printed, 1935.

Bell Telephone Securities. Annual Report of the Bell Telephone Securities Company. New York: privately printed, 1929.

Blair-Smith, H. "1924 Stock Issue of the American Telephone and Telegraph Company.” Bell Telephone Quarterly 3 (1924): 262-269.

_ " "1926 Stock Issue of the American Telephone and Telegraph Company." Bell Telephone Quarterly 5 (1926): 253-265.

_ . "1928 Stock Offer of the American Telephone and Telegraph Company." Bell Telephone Quarterly 7 (1928): 253-265.

"1929 Convertible Bond Offer of the American Telephone and Telegraph Company.” Bell Telephone Quarterly 8 (1929): 316-327.

—_. "1930 Stock Offer of the American Telephone and Telegraph Company." Bell Telephone Quarterly 9 (1930): 250-261.

Chandar, Nandini, and Paul Miranti. "The Development of Actuarial-Based Pension Accounting at the Bell System, 1913-1940." Accounting History 12 (July 2007): 205-234.

Chandar, Nandini, and Paul Miranti, Deirdre Collier, and Paul Miranti. "Graph Standardization and Management Accounting at AT\&T during the 1920s." Accounting History 17, no. 1 (February 2013): 35-62.

Clarke, Sally. "Negotiating Between the Firm and the Consumer: Bell Labs and the Development of the Modern Telephone." In Business and Industry: Culture, Technology Labor, edited by R. Merrill Karen, 161-182. Turnhout, Belgium: BREPOLS, 1998.

Gabel, David, and David F. Weiman. "Historical Perspectives on Competition and Interconnection Between Local Exchange Companies: The United States, 1894-1914.” In Opening Networks to Competition: The Regulation and Pricing of Access, edited by David Gabel and David F. Weiman, 75-105. Boston: Kluwer Academic Publishers, 1998.

Galambos, Louis. "Theodore Vail and the Role of Innovation in the Modern Ball System.” Business History Review 66 (Spring 1992): 95-126.

Gordon, Colin. "Why No Corporatism in the United States? Business Disorganization and Its Consequences.” Business and Economic History 27, no. 1 (Fall 1998): 29-46.

Houston, David. F. The Work of the Bell Telephone Securities Company. Bell Telephone Quarterly 1 (1922): 13-22.

John, Richard. "Theodore Vail and the Civic Origins of Universal Service." Business History Review 66 (Spring 1992): 95-126.

Lipartito, Kenneth. "Rethinking the Invention Factory: Bell Laboratories in Perspective." In The Challenge of Remaining Innovative: Insights from Twentieth-Century American Business, edited by Sally H. Clarke, Naomi R. Lamoreaux, and Steven W. Usselman, 132-159. Stanford, CA.: Stanford Business Books, 2009.

Lipartito, Kenneth. "When Women Were Switches: Technology, Work and Gender.” American Historical Review (October 1994): 1075-1111. 
MacDougall, Robert. "Long Lines: AT\&T's Long-Distance Network as an Organizational and Political Strategy." Business History Review 80, no. 2 (2006): 297-327.

National Industrial Conference Board Inc. Employee Stock Purchase Plans in the United States. New York: National Industrial Confeence Board, 1928.

Navin, Thomas N., and Marian V. Sears. "The Rise of a Market for Industrial Securities, 1887-1902.” Business History Review 29, no. 2 (1955): 105-138. New York Times. "23,480,000 Lines.” Advertising \& Selling Magazine, November 12, 1921, 27. https://books.google.com/books?id=RtFBAQAAMAAJ. Postol, A. H. "Creating the American Newsboy: Middle-Class Route Service and Juvenile Salesmanship in the Great Depression." Journal of Social History 31, no. 2 (1997): 327-345.

Schmoeckel, Mathias. "Liberty In or For the Market? The Legal Response to 'Big Business' in the United States and Germany." In Regulation Between Legal Norms and Economic Reality, edited by Gunther Schulz, Mathias Schmoeckel, and William J. Hausman, 9-51. Tubingen, Germany: Mohr Siebeck, 2014.

Sicilia, D. B. "Selling Power: Marketing and Monopoly at Boston Edison, 1886-1926." Busines and Economic History 20 (1991): 27-31.

Wagner, Markus. "Legal Perspectives and Regulatory Philosophies on Natural Monopolies in the United States and Germany." In Regulation Between Legal Norms and Economic Reality, edited by Gunther Schulz, Mathias Schmoeckel, and William J. Hausman, 53-74. Tubingen, Germany: Mohr Siebeck, 2014.

Weiman, David F. “Building 'Universal Service’ in the Early Bell System: The Coevolution of Regional Urban Systems and Long-Distance Telephone Networks." In History Matters: Essays on Economic Growth, Technology and Demographic Change, edited by Timothy W. Guinnane, William A. Sundstrom, and Warren Whatley, 328-363. Stanford, CA: Stanford University Press, 2004.

\section{Newspapers}

AT\&T Headquarters Bulletin

Harper's Magazine

\section{Archives}

AT\&T Archives, Warrenville, NJ.

Baker Old Class Collection, Baker Library, Harvard Business School, Cambridge, MA.

Federal Communications Commission, National Archives, College Park, MD.

Library, Houghton, David Franklin Houston Papers, Harvard University, Cambridge, MA.

New York Stock Exchange Archives, New York, NY. 